\title{
Liquefaction potential for the Kathmandu Valley, Nepal: a sensitivity study
}

\author{
Rama M. Pokhrel ${ }^{1}$ (D) . Charlotte E. L. Gilder ${ }^{1}$ (D) - Paul J. Vardanega ${ }^{1}$ (D) . \\ Flavia De Luca ${ }^{1}$ D $\cdot$ Raffaele De Risi $^{1}$ ( Maximilian J. Werner ${ }^{2}$ (D) \\ Anastasios Sextos ${ }^{1}$ (D)
}

Received: 2 December 2020 / Accepted: 9 August 2021 / Published online: 23 September 2021 (c) The Author(s) 2021

\begin{abstract}
An assessment of liquefaction potential for the Kathmandu Valley considering seasonal variability of the groundwater table has been conducted. To gain deeper understanding seven historical liquefaction records located adjacent to borehole datapoints (published in SAFER/GEO-591) were used to compare two methods for the estimation of liquefaction potential. Standard Penetration Test (SPT) blowcount data from 75 boreholes inform the new liquefaction potential maps. Various scenarios were modelled, i.e., seasonal variation of the groundwater table and peak ground acceleration. Ordinary kriging, implemented in ArcGIS, was used to prepare maps at urban scale. Liquefaction potential calculations using the methodology from (Sonmez, Environ Geol 44:862-871, 2003) provided a good match to the historical liquefaction records in the region. Seasonal variation of the groundwater table is shown to have a significant effect on the spatial distribution of calculated liquefaction potential across the valley. The less than anticipated liquefaction manifestations due to the Gorkha earthquake are possibly due to the seasonal water table level.
\end{abstract}

Keywords Kathmandu Valley $\cdot$ Seismic hazard $\cdot$ Liquefaction potential · Groundwater table $\cdot$ Kriging

\section{Introduction}

The Kathmandu Valley is located approximately $10 \mathrm{~km}$ from the Main Himalayan Thrust (MHT) (Elliott et al. 2016). This geographical area experienced several destructive earthquakes in the past: the latest significant event occurred in 2015 , the $\mathrm{M}_{\mathrm{w}} 7.8$ Gorkha earthquake (Grandin et al. 2015). The Gorkha earthquake caused structural damage and geotechnical failures, including landslides and liquefaction (e.g., Goda et al. 2015; Chiaro et al. 2015; Hashash et al. 2015; Moss et al. 2015; Sharma and Deng 2019). The thick, sediments underlying the Kathmandu Valley have highly variable geotechnical properties (e.g., Sakai et al. 2008; Gilder et al. 2020) and are prone to liquefy (e.g., Rajendran et al.

Paul J. Vardanega

p.j.vardanega@bristol.ac.uk

Extended author information available on the last page of the article 
2016). However, the study of Moss et al. (2017) demonstrated that evidence of liquefaction in the aftermath of the 2015 Gorkha earthquake was less significant than expected. Possible reasons for this may include: changes in the groundwater table due to extraction (e.g., Pandey et al. 2012); seasonal variation of groundwater table level (Shrestha and Tamrakar 2018) and/or underestimation of soil stiffness (e.g., $V_{S 30}$ ) (cf. Wald and Allen 2007). Jha et al. (2020) compared probabilistic and deterministic approaches for liquefaction potential evaluation in the Kathmandu Valley using two boreholes. In this paper, two deterministic approaches (Iwasaki et al. 1978, 1982, 1984 and Sonmez 2003) are compared using a database of field observations. The observations of Moss et al. (2017) are also tested in this paper.

For the Kathmandu Valley, geotechnical testing (Gilder et al. 2019a; Pokhrel et al. 2019a) and the collection of historical geotechnical investigations (Gilder et al. 2020) have shown that the slope-based prediction of shear wave velocity represents an overestimation for many areas of the valley (Gilder et al. 2018; De Risi et al. 2021). In data-scarce regions, such as the Kathmandu Valley, geostatistical tools may be used to extrapolate results from point locations to a geographical area (e.g., De Risi et al. 2021). Kriging interpolation is often used to determine values for liquefaction potential measures at locations without sufficient geotechnical data (e.g., Baise and Lenz 2006; Maruyama et al. 2010; Pokhrel et al. 2010, 2013, 2012; Thompson et al. 2010; Chung and Rogers 2011; Baker and Faber 2008; Liu and Chen 2006, 2010; Habibullah et al. 2012).

Three new records of liquefaction and four previously documented records of liquefaction within the Kathmandu Valley are examined in this paper. These records are all located in the vicinity of borehole locations collected in the geo-database SAFER/GEO591 (Gilder et al. 2019b, 2020). In this paper, the two reviewed approaches for liquefaction potential determination use the triggering model from Seed and Idriss (1971) and the manifestation models by Iwasaki et al. $(1978,1982,1984)$ and Sonmez (2003) respectively. These approaches are compared against the liquefaction records examined in this study to enable comment on which is the most applicable 'simplified' method for the valley. The approaches are implemented using data from 75 borehole locations (see Table 1) along with the kriging algorithm from ArcGIS to prepare liquefaction maps for variable PGA values and groundwater table levels. Another possible use of SAFER/GE0-591 is to use the data to estimate building settlements (based on SPT $N_{60}$ ) using methodologies such as that described in Valverde-Palacios et al. (2014).

\section{The Kathmandu Valley}

\subsection{Geology}

The Kathmandu Valley is an intermontane basin in the Lesser Himalayas in central Nepal, south of the Great Himalayan Range (e.g., Sakai et al. 2008). The valley is made up of: (a) a basement, metamorphic rock underlying the valley at depth, and (b) younger valley sediments which overly the metamorphic rock formations. Figure 1 shows the liquefaction map of the UNDP/UNCHS (HABITAT) (1993) Subproject "Seismic hazard mapping and risk assessment for Nepal". This project was important as new surficial geological maps were developed based on the details of well data sources originating from the early work done in the Valley. Similarly, the geomorphological map of Yoshida and Igarashi (1984) (Fig. 1b) described a number of sediments resulting from both the Quaternary deposition (recent 
Table 1 Boreholes SAFER/ GEO-591 (Gilder et al. 2019b) used in this study

\begin{tabular}{|c|c|}
\hline No & BH_ID \\
\hline 1 & R_JICA_2002_BH1 \\
\hline 2 & R_JICA_2002_BH2 \\
\hline 3 & R_JICA_2002_BH3 \\
\hline 4 & R_JICA_2002_BH4 \\
\hline 5 & R_JICA_2002_BH5 \\
\hline 6 & RES_Pokh_2006_BH6 \\
\hline 7 & RES_Pokh_2006_BH7 \\
\hline 8 & RES_Safe_2018_BH1 \\
\hline 9 & RES_Safe_2018_BH2 \\
\hline 10 & IND_Bans_2007_BH1 \\
\hline 11 & IND_Bakh_2006_BH3 \\
\hline 12 & R_JRAP_2016_BH4 \\
\hline 13 & R_JRAP_2016_BH2 \\
\hline 14 & R_JRAP_2016_BH5 \\
\hline 15 & R_JRAP_2016_BH3 \\
\hline 16 & R_JRAP_2016_BH1 \\
\hline 17 & IND_Sina_2006_BH1 \\
\hline 18 & IND_Chan_2007_BH4 \\
\hline 19 & IND_Biju_1000_BH1 \\
\hline 20 & IND_Dhob_1000_BH2 \\
\hline 21 & IND_Bhat_2008_BH2 \\
\hline 22 & IND_Sane_2007_BH1 \\
\hline 23 & IND_Taha_2007_BH11 \\
\hline 24 & IND_Ravi_2008_BH1 \\
\hline 25 & IND_Solt_2007_BH1 \\
\hline 26 & IND_Dhum_2007_BH2 \\
\hline 27 & IND_Pani_2008_BH1 \\
\hline 28 & IND_Lazi_2008_BH3 \\
\hline 29 & IND_Kule_2007_BH1 \\
\hline 30 & IND_Sane_1000_BH3 \\
\hline 31 & IND_Kupo_1000_BH1 \\
\hline 32 & IND_Sank_2008_BH1 \\
\hline 33 & IND_Kama_2008_BH1 \\
\hline 34 & IND_Pulc_2008_BH1 \\
\hline 35 & IND_Solt_2008a_BH1 \\
\hline 36 & IND_Dill_2008_BH2 \\
\hline 37 & IND_Gyan_2008_BH2 \\
\hline 38 & IND_Sane_2009_BH5 \\
\hline 39 & IND_Bish_2007_BH5 \\
\hline 40 & IND_Sano_2008_BH2 \\
\hline 41 & IND_Sane_1001_BH1 \\
\hline 42 & IND_Hatt_1000_BH6 \\
\hline 43 & IND_Balk_2009_BH2 \\
\hline 44 & IND_Sane_1002_BH1 \\
\hline 45 & IND_Dhap_2009_BH1 \\
\hline 46 & IND_Ghat_2009_BH4 \\
\hline 47 & IND_Kada_1000_BH10 \\
\hline 48 & IND_Sane_2009a_BH3 \\
\hline 49 & IND_Thad_2009_BH1 \\
\hline
\end{tabular}


Table 1 (continued)

\begin{tabular}{|c|c|}
\hline No & BH_ID \\
\hline 50 & IND_Baba_2008_BH2 \\
\hline 51 & IND_Balk_2009a_BH2 \\
\hline 52 & IND_Batt_2005_BH3 \\
\hline 53 & IND_Solt_2008_BH1 \\
\hline 54 & IND_Naxa_1000_BH1 \\
\hline 55 & IND_Naxa_1000_BH2 \\
\hline 56 & IND_Naxa_1000_BH3 \\
\hline 57 & IND_Hanu_1002_BH1 \\
\hline 58 & IND_Hanu_1002_BH2 \\
\hline 59 & IND_Balk_2009b_F2 \\
\hline 60 & IND_Dhap_2008_BH9 \\
\hline 61 & IND_Bakh_2006_BH1 \\
\hline 62 & IND_Jaga_2010_BH1 \\
\hline 63 & IND_Kote_2008_BH1 \\
\hline 64 & IND_Kaus_2017_BH1 \\
\hline 65 & IND_Kaus_2017_BH2 \\
\hline 66 & IND_Kaus_2017_BH3 \\
\hline 67 & IND_Goda_2018_BH1 \\
\hline 68 & IND_Bala_2018_BH1 \\
\hline 69 & IND_Chys_2015_BH1 \\
\hline 70 & RES_Daha_2002_BH4 \\
\hline 71 & RES_Pagl_2018_BH1 \\
\hline 72 & RES_Kate_1996_T2 \\
\hline 73 & RES_Kate_1996_R1 \\
\hline 74 & Bungmati-1 (Jha et al. 2020) \\
\hline 75 & Bungmati-2 (Jha et al. 2020) \\
\hline
\end{tabular}

sediment deposits near rivers) and earlier Pliocene to Pleistocene deposits from a variety of depositional environments including fluvio-deltaic, laucustrine and deltaic (Sakai et al. 2008).

The geological map in Fig. 2 indicates the newer geological designations from Shrestha et al. (1998). The Kalimati Formation beneath any recent deposits in the central Valley (Fig. 1c) (Paudel and Sakai 2009) often consists of a laminated black clayey, silt interlaminated with silt, clay and with very fine, silty, sand layers. The Sunakothi Formation, present in much of the southern part of the Valley, contains both clayey sequences and laminated silts and sands. The Terrace deposits contain coarser materials, skirting the bedrock geology of the southern central and western margins. When examining Fig. 1b, it can be seen how the original liquefaction map (Fig. 1a) was defined. Where rivers are present (with presumably saturated soils) these areas represent the position of highest liquefation potential. This potential reduces towards the valley edge. More recent assessments have indicated that the highest potential is at locations near the rivers and in the central valley (Gautam et al. 2017), and probabilistic assessments have reported similar findings (Sajan et al. 2020; Khatakho et al. 2021). However, this has been attributed to the older sequences and as the Valley contains a complex mix of laminated sequences it remains a challenge to evaluate the liquefaction potential in the valley. It is likely much of the valley mapping is affected by recent superficial deposits (which are not currently shown on maps) due to 

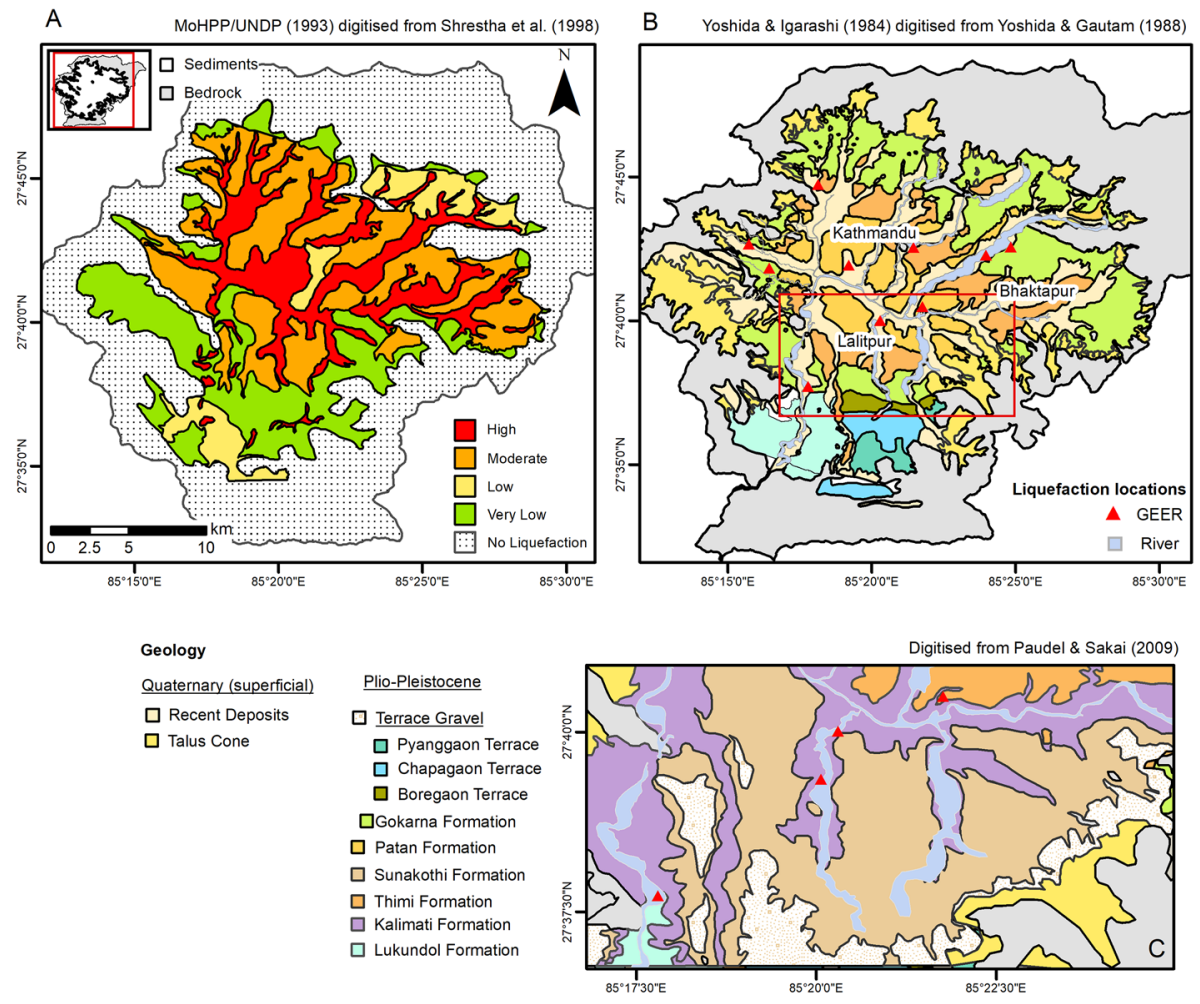

Fig. 1 a Liquefaction map, UNDP/UNCHS (HABITAT) (1993), digitised map data from Shrestha et al. (1998) b Kathmandu Valley sediments based on geomorphological distribution from Yoshida and Igarashi (1984), digitised map data from Yoshida and Gautam (1988) c map of Plio-Pleistocene sediments, digitised map data from Paudel and Sakai (2009)

the likely occurance of channel movement and geomorphic development of the river basin (Shrestha and Tamrakar 2013). Age relationships of the soils shown in Fig. 1 are inexact due to the combination of map sources. For instance, more recent Cone Penetration Testing (CPT) work has suggested that some locations near rivers are unlikely to liquefy (Gilder et al. 2021) but also the position of the Araniko Highway movement is upon a relict river channel. These conclusions (Gilder et al. 2021) are also currently affected by the ability to assess the silts of this region for liquefaction potential due to the limited amount of geotechnical field and laboratory testing. Herein, the aim is to improve understanding of potential seasonal variation of liquefaction potential and to compare the modelled results to observations taken following the 2015 Gorkha earthquake.

\subsection{Historical earthquakes and faults}

Table 2 lists the significant historical earthquakes recorded in the Kathmandu Valley. The most devastating earthquakes occurred in 1833, 1866, 1934, 1988, and 2015 (Rana 1935; Bilham 1995, 2019; Pandey et al. 2002; Pandey and Molnar 1988; Goda et al. 2015). Prior studies considered a fault system containing three main faults, namely the main central thrust (MCT), main boundary thrust (MBT) and himalayan frontal thrust (HFT) (e.g., 


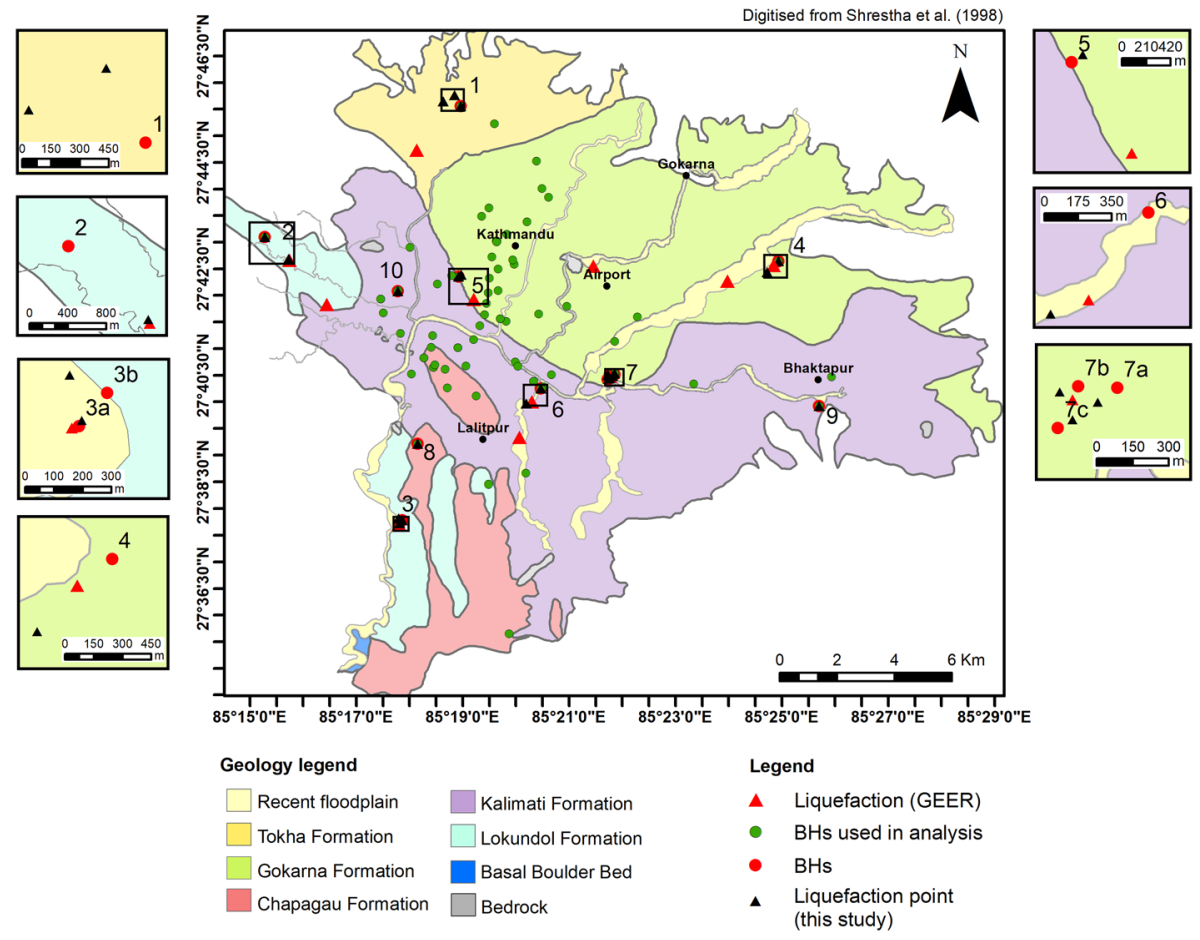

Fig. 2 Engineering geological map with liquefaction validations points indicated with the IDs provided in Table 6 and zoomed areas to indicate distance between the liquefaction point identified in this study (black triangle) and validation borehole (red circle). The historical liquefaction points evidenced by the field study Geotechnical Extreme Event Reconnaissance (GEER) (locations given in Hashash et al. 2015) are also shown (red triangles). Recent deposits have been added to map data digitised from Shrestha et al. (1998) map to reflect true extent of rivers

Table 2 Historical earthquakes that caused severe damage in the Kathmandu Valley

\begin{tabular}{llll}
\hline Date & $\begin{array}{l}\text { Moment } \\
\text { magnitude } \\
\left(M_{w}\right)\end{array}$ & Location & References \\
\hline August 26, 1833 & 7.8 & North of Kathmandu Valley & Pandey and Molnar (1988); Bilham (1995) \\
May 23, 1866 & 7.0 & North of Kathmandu & Szeliga et al. (2010) \\
Jan 15, 1934 & 8.4 & Udayapur, Nepal & Rana (1935); Chen and Molnar (1977) \\
August 21, 1988 & 6.5 & Udayapur, Nepal & Bilham (2019) \\
April 25, 2015 & 7.8 & Gorkha, Nepal & Goda et al. (2015) \\
May 13, 2015 & 7.3 & Kodari, Nepal & Goda et al. (2015) \\
\hline
\end{tabular}

Chaulagain et al. 2015). The maximum PGA generated for the Kathmandu Valley by the earthquakes from these thrusts is around $0.35 \mathrm{~g}$; consistent with the old building code of Nepal (1994) (NBC 1994). Publications after the 2015 Gorkha earthquake have better described the geometry of the main himalayan thrust (MHT) beneath the Kathmandu 
Valley (Elliott et al. 2016) and highlighted that the MHT could generate an earthquake as great as magnitude $\mathrm{M}_{\mathrm{W}} 9.0$ (Stevens et al. 2018; Pokhrel et al. 2019b). The new building code for Nepal (NBC 2020), specifies a maximum PGA value for the Kathmandu valley of $0.35 \mathrm{~g}$ for a 475 -year return period. PSHA results are significantly affected by the specific choice of GMPEs assumed (Stevens et al. 2018; De Risi et al. 2020). Taking the MHT as a single seismogenic source, the PGA can vary significantly depending on the GMPE used.

\subsection{Groundwater level and water table}

Nepal lies in a humid-subtropical climatic region with dry-winters (Kottek et al. 2006) and heavy rain-summers. During the rainy seasons, monsoons last from mid-June to midSeptember (approximately 90 days) during which time the average rainfall is more than $1000 \mathrm{~mm}$ (Pokharel and Hallett 2015). The large population of 2.5 million (CBS 2012) living in the Kathmandu Valley use groundwater for domestic and commercial purposes. If consumption exceeds the recharge of the groundwater in the dry season, the change in height of the groundwater table at the end of this season can be as much as $5 \mathrm{~m}$ (e.g., Shrestha and Tamrakar 2018). According to Moss et al. (2017), groundwater withdrawal in the Kathmandu Valley over the last decades resulted in a drop of the average water table in the valley. This is also supported by Pandey et al. (2012), who reported that $60-70 \%$ of the water supply during the dry season comes from groundwater with a consequent drawdown up to $7.5 \mathrm{~m}$ from 2000 to 2008. Moss et al. (2017) estimated an average annual groundwater drawdown of roughly $1 \mathrm{~m}$ per year and assumed a variable water table depth derived from the global water table database by Fan et al. (2013). For the purposes of liquefaction assessment the Moss et al. (2017) groundwater model ranged between 0 and 40 m within the sediment deposits in the central Valley. However, the seasonal variation of the groundwater table for particular deposits was not explicitly considered.

Shrestha and Tamrakar (2018) mapped the shallow groundwater level for dry (pre-monsoon) and wet (monsoon) season in the northern part of the Kathmandu Valley. In particular, data from 239 wells were collected during wet and dry season, allowing an average estimation of seasonal variation of the groundwater level. In this study, using the observations of Shrestha and Tamrakar (2018):

- $1.6 \mathrm{~m}$ is taken as the approximate value for the water table in the wet season, estimating it as the average depth minus one half of the standard deviation from the data reported in Shrestha and Tamrakar (2018).

- $5.1 \mathrm{~m}$ is taken as the approximate value for the water table in the dry season, estimating it as the average depth plus one half of the standard deviation from the data reported in Shrestha and Tamrakar (2018).

These assumptions do not allow for the spatial variation of the groundwater table (cf. Fan et al. 2013). However, the aim herein is to study seasonal variation of the groundwater table in conjunction with variability of the PGA as obtained from recent probabilistic hazard assessment studies. 


\section{Methodology}

\subsection{Liquefaction potential calculation}

Seed and Idriss (1971) proposed a method to assess liquefaction resistance of soils. In this approach, the factor of safety against liquefaction $\left(F_{L}\right)$ is determined by the ratio between the cyclic resistance ratio (CRR) and the earthquake-induced cyclic stress ratio (CSR) (see Sonmez (2003) for further commentary on the historical development of this approach). This method is widely used as a triggering model to evaluate the factor of safety against liquefaction $F_{L}$ (e.g., Geyin et al. 2020). $F_{L}$ is used to evaluate if a soil layer is susceptible or non-susceptible to liquefaction during an earthquake.

Iwasaki et al. (1984) proposed a liquefaction potential index $\left(I_{L}\right)$ to evaluate the liquefaction potential in multiple layers of soil. The liquefaction potential index $\left(I_{L}\right)$ in Iwasaki et al. (1984) is referred to in this paper as the liquefaction potential $\left(P_{L}\right)$; this parameter assumes that surface manifestation depends on the thicknesses of all strata that can liquefy in the uppermost $20 \mathrm{~m}$ of a soil column, their proximity to the ground surface, and the amount by which the factor of safety against liquefaction in each stratum $\left(F_{L}\right)$ is less than 1.0 (Geyin et al. 2020). The methodology of Iwasaki et al. (1984) was also used in the work of Piya et al. (2004) who presented both qualitative and quantitative liquefaction potential assessments for the Kathmandu valley using the available SPT data at that time.

Equation 1 gives the function of the liquefaction resistance factor, $F(z)$, is expressed through Eq. 2 and the depth weighting factor, $W(z)$, is expressed through Eq. 3 in which $z$ represents the depth of the midpoint of the soil layer from the surface.

$$
\begin{gathered}
P_{L}=\int_{0}^{20} F(z) \cdot W(z) d z \\
F(z)= \begin{cases}1-F_{L} & \text { for } F_{L} \leq 1 \\
0 & \text { for } F_{L}>1\end{cases} \\
W(z)= \begin{cases}10-0.5 \cdot z \text { for } z \leq 20 m \\
0 & \text { for } z>20 m\end{cases}
\end{gathered}
$$

Sonmez (2003) modified $P_{L}$ based on data from Inegol (Turkey) and Sonmez and Gokceoglu (2005) modified $P_{L}$ based on data from Yuanlin (Taiwan). The assumption for $F(z)$ to be used in Eq. 1 was modified according to Eq. 4 to incorporate marginally liquefiable strata ('moderate') (characterised by $F_{L}$ in the range [0.95-1.2], Sonmez (2003)).

$$
F(z)= \begin{cases}1-F_{L} & \text { for } F_{L} \leq 0.95 \\ 2 \cdot 10^{6} \cdot e^{-18.427 F_{L}} & \text { for } 0.95<F_{L}<1.2 \\ 0 & \text { for } F_{L} \geq 1.2\end{cases}
$$

Comparison of the approaches of Iwasaki et al. (1984) and Sonmez (2003) was also presented in Liu (2008). In the present study, the methodologies by Iwasaki et al. (1984) and Sonmez (2003) were used to evaluate the liquefaction potential in the Kathmandu valley using new case evidence from the Gorkha earthquake and geotechnical investigations from 
Table 3 Summary of the mean $D_{50}$ and $\rho_{\text {soil }}$ values for Kathmandu Valley from SAFER/ GEO-591 (Gilder et al. 2019b); $n=$ number of data points used to compute the stated averages

\begin{tabular}{|c|c|c|c|c|c|c|}
\hline \multirow[t]{3}{*}{ Soil Type } & \multicolumn{6}{|c|}{ SAFER/GEO-591 } \\
\hline & \multicolumn{3}{|c|}{$\overline{\mathrm{D}_{50}(\mathrm{~mm})}$} & \multicolumn{3}{|c|}{$\rho_{\text {soil }}\left(\mathrm{g} / \mathrm{cm}^{3}\right)$} \\
\hline & mean & $\mathrm{n}$ & $\min$ & mean & $\max$ & $\mathrm{n}$ \\
\hline Surface soil & - & - & - & - & - & - \\
\hline Clay & - & - & 1.49 & 1.75 & 1.99 & 22 \\
\hline Silt & 0.011 & 11 & 1.54 & 1.82 & 2.19 & 17 \\
\hline Sandy silt & 0.041 & 6 & & & & \\
\hline Silty sand & - & - & 1.65 & 1.88 & 2.28 & 122 \\
\hline Fine sand & 0.380 & 27 & & & & \\
\hline \multicolumn{7}{|l|}{ Medium sand } \\
\hline \multicolumn{7}{|l|}{ Coarse sand } \\
\hline Gravelly sand & 0.710 & 5 & - & - & - & - \\
\hline
\end{tabular}

the SAFER/GEO-591 geo-database (Gilder et al. 2019b). Table 3 shows the $D_{50}$ and $\rho_{\text {soil }}$ values used for the liquefaction potential analysis. Figure 3 shows the grain-size distribution curves from the SAFER/GEO-591 geo-database against the "liquefiable" and "potentially liquefiable" bounds from Tsuchida (1970) and Koester and Tsuchida (1988). These distribution curves are mainly concentrated in the liquefiable boundary emphasising a potential for high susceptibility.

\subsection{Historical records of liquefaction in the Kathmandu Valley}

Photographs taken immediately after the Nepal-Bihar earthquake show fractures developed in the field associated with sand boiling (Rana 1935). After the Nepal-Bihar earthquake, eyewitness accounts describe liquefaction evidenced by observations of sand boiling and soil fissuring. Photographic reports from Rana (1935) show "ground fissures after sand boiling" in the central part of Kathmandu city (location 5 in Fig. 2), in Tundikhel (Rana 1935). Similarly, during the 2015 Gorkha earthquake further evidence was observed. Table 4 details seven documented liquefaction records in the Kathmandu Valley which are

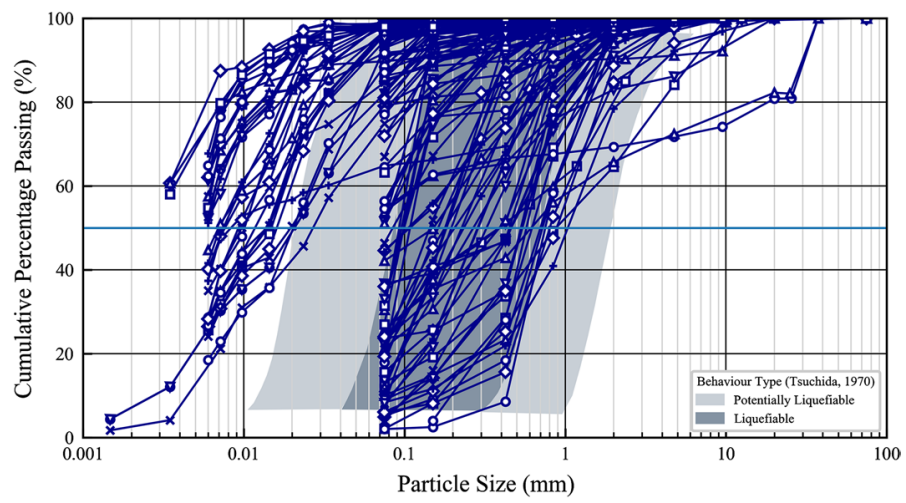

Fig. 3 Grain-size distribution curves from SAFER/GEO-591, liquefaction bounds attributed to Tsuchida (1970) digitized from Koester and Tsuchida (1988) 
Table 4 Approximate liquefaction evidence point co-ordinates and evidence details extracted from GEER report (Hashash et al. 2015)

\begin{tabular}{llll}
\hline Location & Latitude $^{\circ} \mathrm{N}$ & Longitude $^{\circ} \mathrm{E}$ & $\begin{array}{l}\text { Evidence (page(s) refer- } \\
\text { ence from Hashash et al. } \\
2015)\end{array}$ \\
\hline Ramkot & 27.711025 & 85.26229 & $106-108$ \\
Singa Durbar Bridge & 27.698793 & 85.32006 & $108-109$ \\
Manamaiju & 27.745523 & 85.302223 & $109-110$ \\
Guheshwor & 27.709253 & 85.357553 & $110-111$ \\
Lokanthali & 27.674816 & 85.362646 & $111-118$ \\
Syuchatar & 27.697230 & 85.274080 & $118-119$ \\
Bungamati & 27.628630 & 85.296650 & 119 \\
Changu Narayan & 27.709430 & 85.413970 & 120 \\
Mulpani & 27.704575 & 85.399617 & 121 \\
Gwarko/Imadol & 27.666782 & 85.338346 & 121 \\
Hattiban & 27.655670 & 85.334410 & $121-122$ \\
\hline
\end{tabular}

Table 5 Approximate locations of liquefaction evidence photographs provided in the Appendix

\begin{tabular}{llllll}
\hline $\begin{array}{l}\text { Table 6 } \\
\text { Reference }\end{array}$ & Photo & Location & Latitude ${ }^{\circ} \mathrm{N}$ & Longitude ${ }^{\circ} \mathrm{E}$ & Evidence \\
\hline 3a & Figure 10 & Bungmati & 27.62886 & 85.29696 & Cracking and sand boiling ejecta \\
$3 \mathrm{~b}$ & Figure 11 & Bungmati & 27.63028 & 85.29659 & Cracking and sand boiling ejecta \\
6 & Figure 12 & Imadol & 27.66614 & 85.33656 & Tilted building \\
$7 \mathrm{a}$ & Figure 4 & Kausaltar & 27.67473 & 85.36359 & Ground fracture \\
$7 \mathrm{~b}$ & Figure 5a & Kausaltar & 27.67512 & 85.36217 & Tilted building \\
$7 \mathrm{c}$ & Figure 5b & Kausaltar & 27.67407 & 85.36265 & Ground fracture \\
\hline
\end{tabular}

located near to boreholes locations in the SAFER/GEO-591 geo-database also reported in Fig. 2. In Fig. 2 the locations evidenced in the geotechnical extreme event reconnaissance (GEER) (Hashash et al. 2015 and Table 4) field studies are compared. Those that do not feature in Table 6, did not have an accompanying quality borehole record. In Table 5 the locations from this study are detailed, locations $7 \mathrm{a}, 7 \mathrm{~b}$ and $7 \mathrm{c}$ represent new data collected in the aftermath of the Gorkha earthquake by the first author. All evidence data (i.e., photographic documentation and borehole details from SAFER/GEO-591) are provided in this paper (Tables 1, 4 and 5 and Figs. 10, 11, 12, 13, 14 and 15 in the Appendix). The $P_{L}$ and the corresponding liquefaction potential category according to Iwasaki et al. (1984) and Sonmez (2003) are compared: both methodologies give similar computed values of liquefaction potential with Sonmez providing slightly higher $P_{L}$ values (see Table 6) leading to a refined estimate. However, both estimates remain quite similar. Figure 4 shows a ground fissure at Kausaltar, Bhaktapur (Location 7a in Fig. 2), after the 2015 Gorkha earthquake. Figure 5a shows evidence of a building tilted due to liquefaction effects; this building was situated near the Araniko Highway, corresponding to Location $7 \mathrm{~b}$ in Fig. 2. Figure 5b shows the liquefaction evidence record for Location 7c in Fig. 2. 


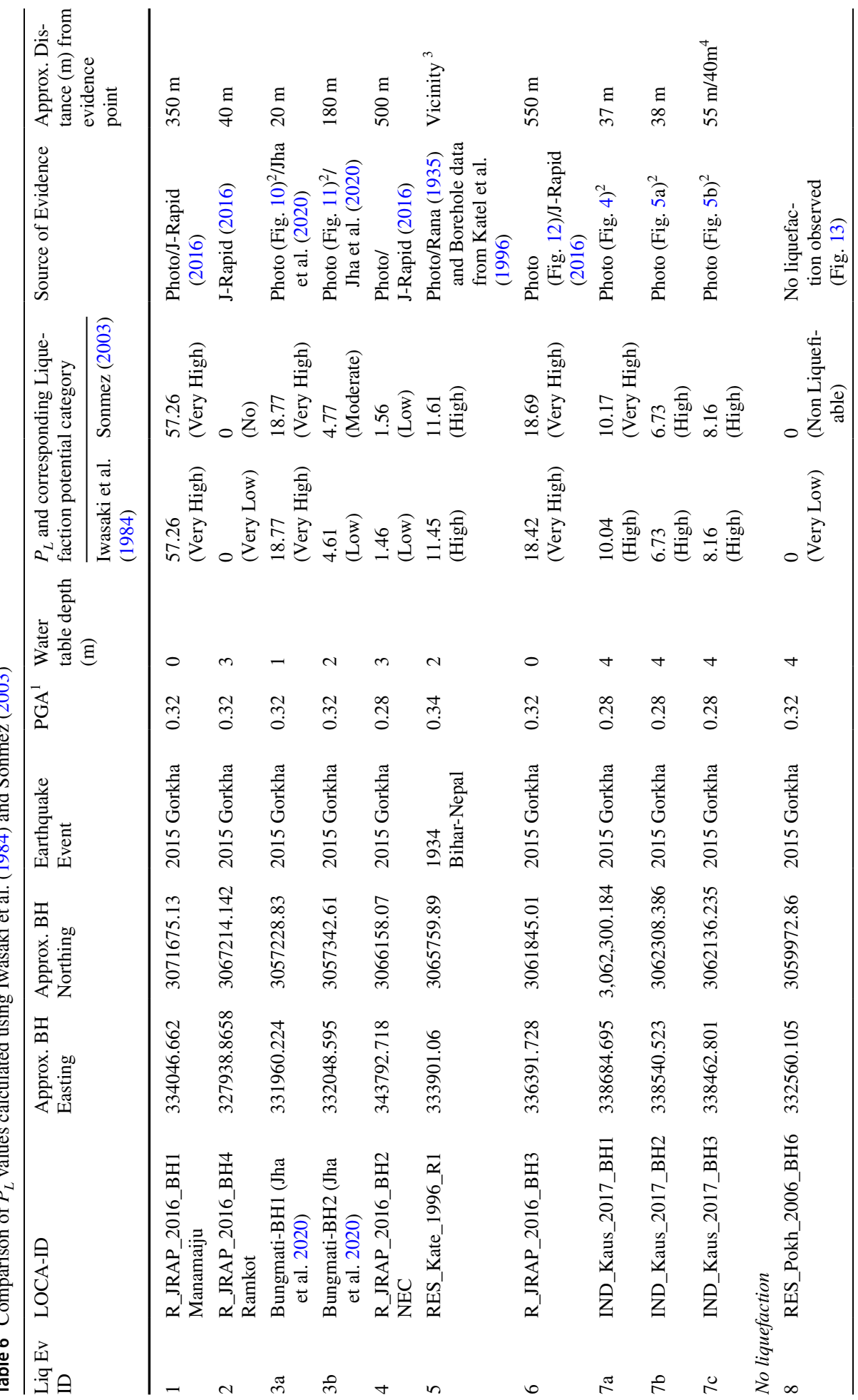




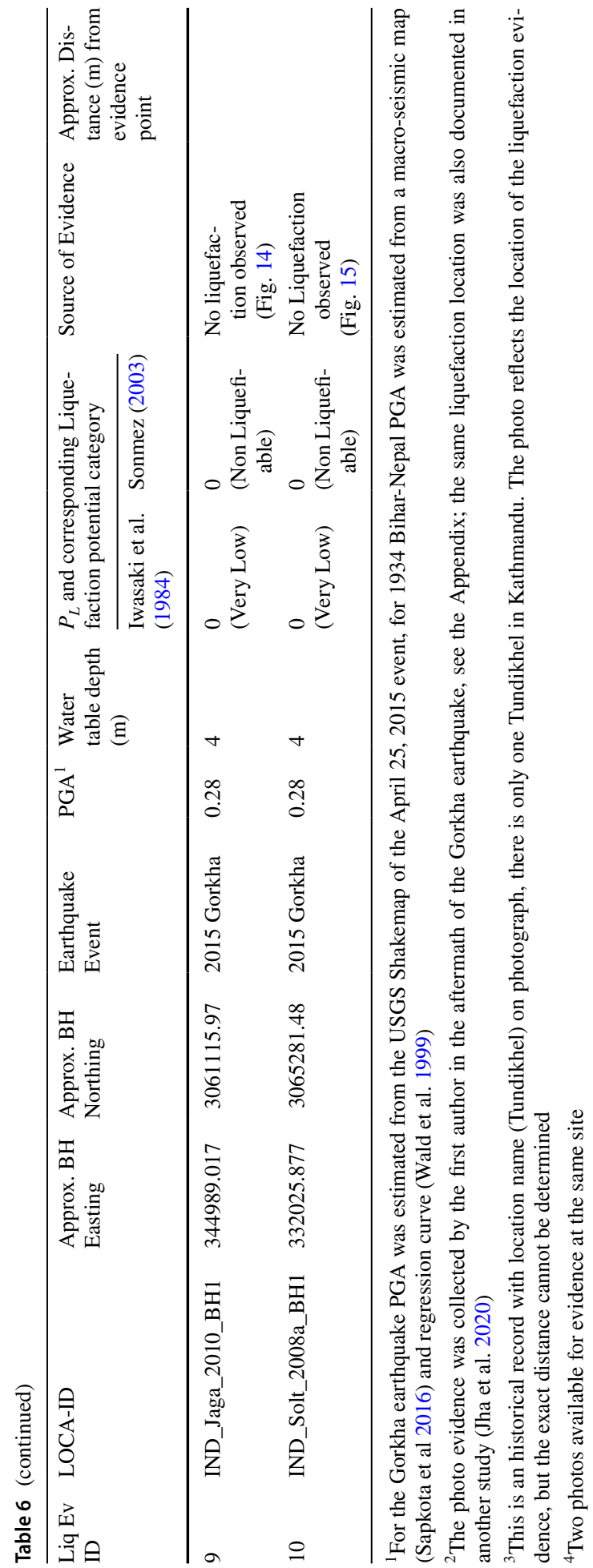


Fig. 4 Liquefaction and cracks in the ground at Kausaltar, Bhaktapur, Nepal, after the 2015 Gorkha earthquake, (Location $7 \mathrm{a}$ on Fig. 2). Photograph taken on 2015-05-31 [RM Pokhrel]

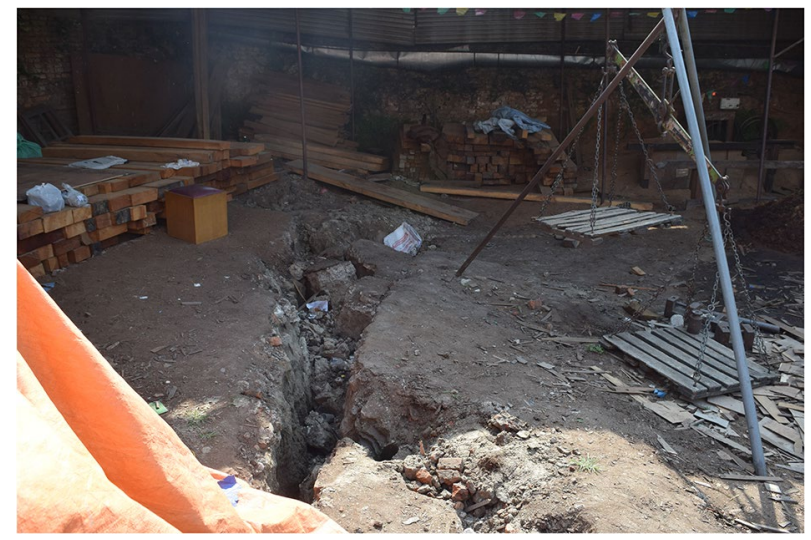

Photographic evidence collected by the first author in the aftermath of Gorkha earthquake and located in the vicinity of three boreholes from the SAFER/GEO-591 database (Gilder et al. 2019b) showed no evidence of liquefaction. These locations are indicated as 8, 9 and 10 in Table 6 are employed as "evidence of no liquefaction" to compare the performances of the two approaches of Iwasaki et al. (1984) and Sonmez (2003). For all three IDs 8,9 and 10, the resulting $P_{L}$ value is 0 predicting very low and non-liquefiable potential categories for Iwasaki et al. (1984) and Sonmez (2003), respectively (see Table 6).

\subsection{Zoning}

Sonmez's (2003) methodology was found to be better suited for classification of computed $P_{L}$ values based on the evidence presented in this paper for the Kathmandu Valley. Application of the methodology can provide $P_{L}$ estimates at 75 discrete locations using SAFER/ GEO-591 (Gilder et al. 2019b) (see Table 1 for a list of the boreholes used from SAFER/ GEO-591). The final number of boreholes employed is due to the selection of higher quality investigations i.e., the deepest boreholes are used with availability of other geotechnical information) when multiple investigations are available at the same site. To draw liquefaction potential maps for the region kriging interpolation can be used. Kriging interpolation allows for the degree of variation among known data points and corresponding distance to estimate values in unknown areas (e.g., Baise et al. 2006; Thompson et al. 2010; Chung and Rogers 2011; Pokhrel et al. 2012, 2013; Thompson et al. 2014). In this paper, the adopted algorithm is the ordinary kriging approach implemented in ArcGIS (ESRI 2012). Given kriging is an interpolation method and that soils are highly variable the results from the maps shown in this paper should not be used for site-specific design work but rather as a useful guide for planning future infrastructure developments.

\section{Liquefaction potential map for Kathmandu Valley}

\subsection{Seismic hazard}

PGA values for the Kathmandu Valley are those based on the PSHA results provided by Stevens et al. (2018). As discussed in several studies (e.g., Stevens et al. 2018; Pokhrel 
et al. 2019b; De Risi et al. 2020), the hazard in the region is dominated by the MHT; however, the study by Stevens et al. (2018) considered several additional sources contributing to the hazard. Furthermore, the assumption related to the GMPEs in the PSHA can significantly affect hazard results. There remains significant uncertainty related to the choice of GMPEs for PSHA studies in the Himalayan region and the lack of regional GMPEs supported by a significant number of data (e.g., Bajaj and Anbazhagan 2019). Stevens et al. (2018) employed an equally weighted logic tree in their PSHA, i.e., using an average of four GMPEs. Additionally, each GMPE was considered separately (data available in Stevens 2020).

The PGA maps for a probability of exceedance of $2 \%$ and $10 \%$ in 50 years are considered as they refer to the near-collapse and life safety reference in many international seismic codes (e.g., CEN 2004). The estimates of PGA employed for the Kathmandu Valley in this study are: (i) the final values provided in Stevens et al. based on the average of the four GMPEs considered defined as AVERAGE in the following and (ii) the PGA estimate resulting from the use of the GMPE from Atkinson and Boore (2003) indicated in the following as AB03. The first assumption was the inclusion of GMPEs suitable for crustal and subduction zones, and none of them being region-specific for the Himalaya given the lack of data and the further necessity to develop reliable GMPEs for the area (see also Bajaj and Anbazhagan 2019). The second assumption refers to the subduction GMPE proposed by Atkinson and Boore (2003), which is not region-specific but can be used as a lower bound for PGA for the Kathmandu Valley. Figures 6 and 7 show the PGA maps for the 2\% and $10 \%$ in 50 years probability of exceedance considering both the AVERAGE (Fig. 6) and AB03 (Fig. 7) GMPE assumptions. Both PGA maps were calculated accounting for the local soil amplification in the basin. This was achieved using the $V_{S 30}$ used as the parameter for soil characterization using the GMPEs. The source for $V_{S 30}$ used in the GMPEs for the PSHA study (Stevens et al. 2018) was the USGS slope-based study by Wald and Allen (2007) and Allen and Wald (2009). This approach tends to overestimate the $V_{S 30}$ values (i.e. soil-stiffness) with respect to direct measurements, as shown in Gilder et al. (2018). For the geomorphological condition and complex geology of the Kathmandu Valley, the slope model does not represent an accurate approximation of $V_{S 30}$ (De Risi et al. 2021) but it is considered suitable at this stage for the scope of zoning liquefaction potential.

A

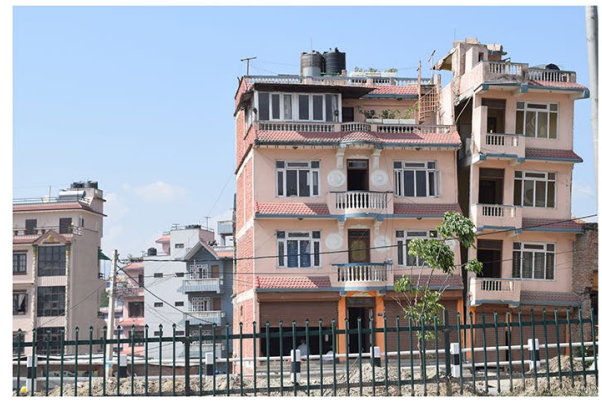

B

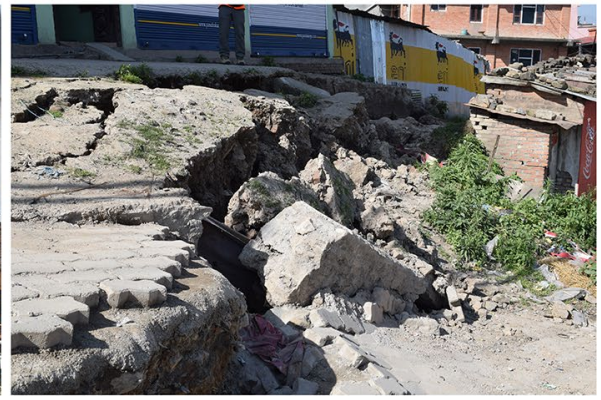

Fig. 5 a Partial collapse due to tilting and seismic pounding in the Kausaltar area (Location 7b in Fig. 2) after the Gorkha earthquake; b liquefaction and cracks in the ground near the Araniko Highway at Kausaltar, Bhaktapur, as a result of the Gorkha Earthquake 2015, (Location 7c on Fig. 2). Photograph taken on 2015-05-31 [RM Pokhrel] 

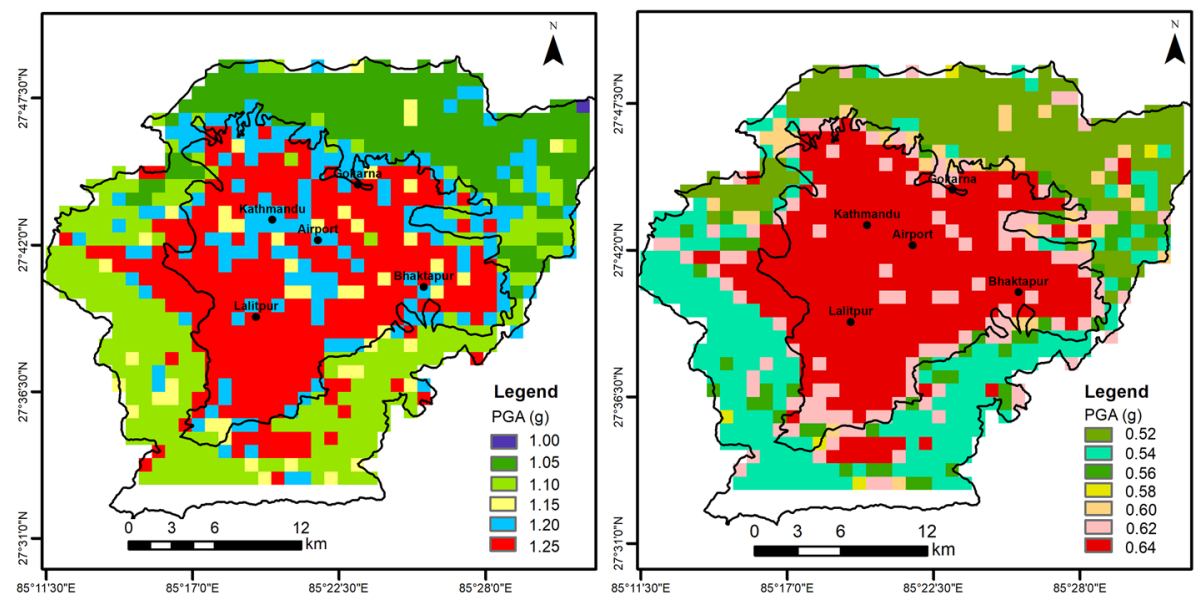

Fig. 6 PGA map (horizontal component) of the Kathmandu Valley for a (left) $2 \%$ in 50 years probability of exceedance and $\mathbf{b}$ (right) $10 \%$ in 50 years probability of exceedance assuming the AVERAGE GMPE model choice by Stevens (2020) (data from Stevens 2020)
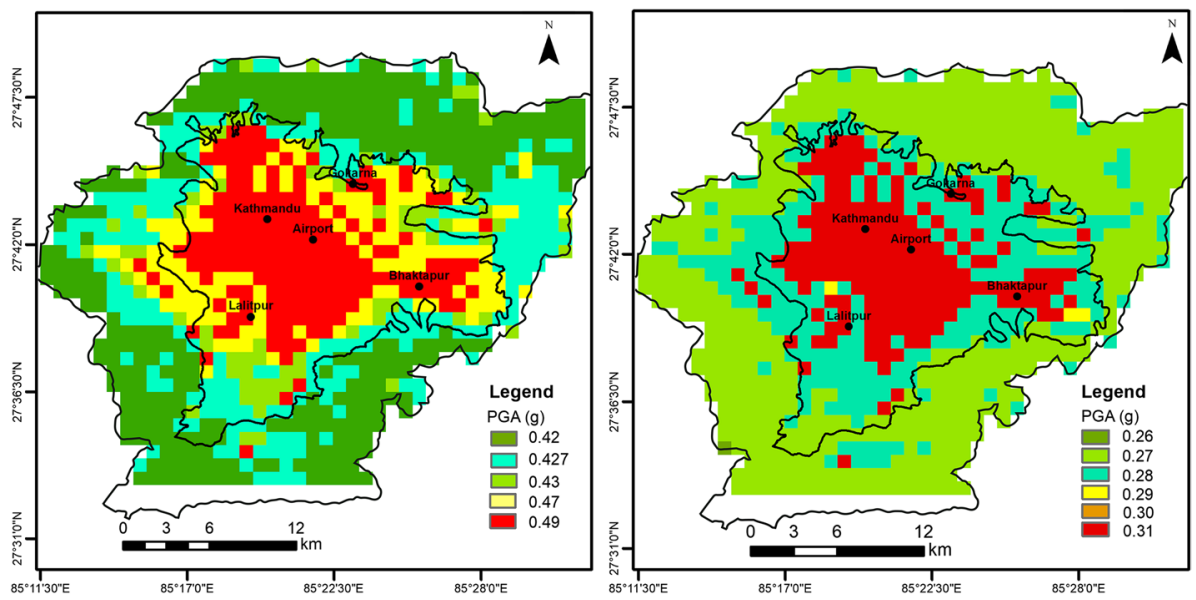

Fig. 7 PGA map (horizontal component) of the Kathmandu Valley for a (left) $2 \%$ in 50 years probability of exceedance and $\mathbf{b}$ (right) $10 \%$ in 50 years probability of exceedance assuming the AB03 GMPE as provided by Stevens (2020) (data from Stevens 2020)

\subsection{Results and discussion}

The results are presented for a range of PGA values, obtained from an average representing several GMPEs, (GMPE AVERAGE of Stevens 2020) and a single GMPE (AB03 of Stevens 2020) as shown in Fig. 6 and Fig. 7. These figures indicate the uncertainty in the prediction. The geographical resolution of the data is at the order of approximately $1000 \mathrm{~m}$.

At each borehole location in the SAFER/GEO-591 database used for the liquefaction potential analysis, two different seasonal values of water table depth were used $(1.6 \mathrm{~m}$ and $5.1 \mathrm{~m})$ as discussed in Sect. 2. Figure $8 \mathrm{a}$ and $\mathrm{b}$ show the liquefaction potential map of the 

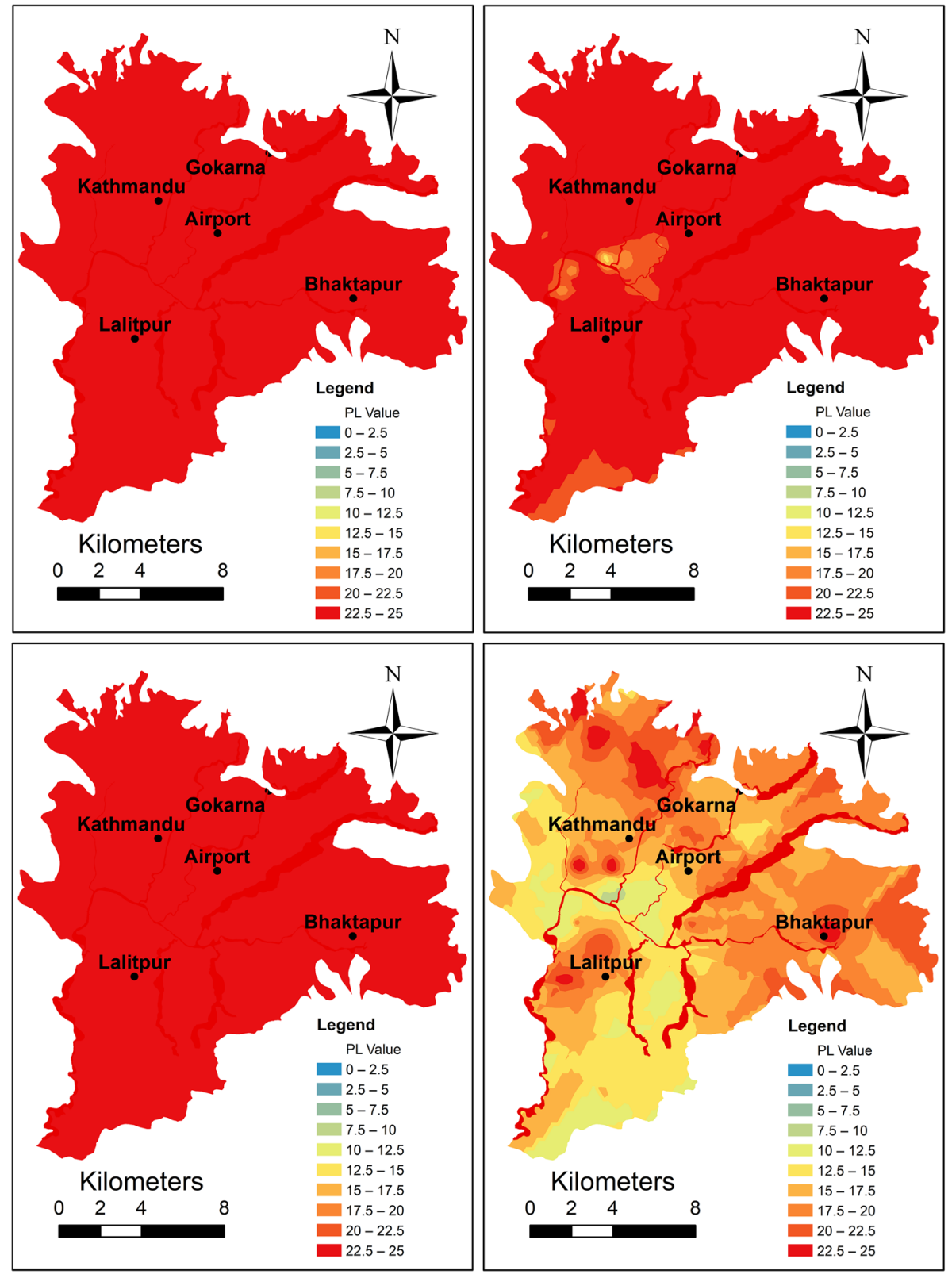

Fig. 8 Liquefaction potential map of the Kathmandu Valley based on PGA assuming an AVERAGE GMPE for $2 \%$ in 50 years probability of exceedance under a a (top-left) wet scenario and $\mathbf{b}$ (top-right) dry scenario and for $10 \%$ in 50 years probability of exceedance in a c (bottom-left) wet scenario and $\mathbf{d}$ (bottom-right) dry scenario, respectively

Kathmandu Valley based on PGA considering the AVERAGE GMPE assumption for 2\% in 50 years probability of exceedance under a wet scenario and dry scenario, respectively. 
Similarly, Fig. $8 \mathrm{c}$ and d present $10 \%$ in 50 years probability of exceedance in a wet scenario and dry scenario, respectively. Among these, the PGA having $2 \%$ probability of exceedance in 50 years is around $1.2 \mathrm{~g}$, and it is almost uniform across the valley. This represents the worst-case scenario of a wet season earthquake where both the sandy deposits and silty or fine-grained materials (characterizing the southern valley) are saturated and so have the potential to liquefy. On the other hand, the PGA for a probability of exceedance of $10 \%$ in 50 years is around $0.65 \mathrm{~g}$, and it is more spatially variable (i.e., borehole to borehole). Severe liquefaction is anticipated all around the Kathmandu valley for these PGA values and with an assumed depth of groundwater table of $5.1 \mathrm{~m}$ during the dry season. In this scenario, most of the Kathmandu Valley has a high computed potential for liquefaction. Similarly, Fig. 9a and b present liquefaction potential maps of the Kathmandu Valley based on PGA considering only the AB03 GMPE for $2 \%$ in 50 years probability of exceedance under a wet scenario and dry scenario, respectively. Figure $9 \mathrm{c}$ and d show the liquefaction potential for $10 \%$ probability of exceedance in 50 years in a wet scenario and dry scenario, respectively. The estimated PGA for the $2 \%$ probability of exceedance in 50 years is about $0.48 \mathrm{~g}$ and for $10 \%$ it is about $0.3 \mathrm{~g}$, closer to the current design PGA in the Nepalese building code (NBC 2020).

An important geotechnical aspect is the superficial geology, the liquefiable layers are due to the presence of the river (supported by the GEER evidence, Hashash et al. 2015). However, when considering the distribution of the liquefaction potential in Fig. 8d in the central Valley, most areas correspond with the Somnez designation 'moderate' when located adjacent to the river edge. Two boreholes located between Kathmandu and Lalitpur either side of the river help evidence this result, and this probably is due to the dominant silt and clay-like materials often present at depth at these locations. The spatial position of these points (and the kriging results) gives lower values of potential liquefaction. As this indicates the 'dry scenario', the saturation in such deposits will be lower. Considering the laminated nature of the deposits and the fact that many locations are without borehole data, the results presented in this work are preliminary.

The flood plain areas have been identified and considered as having a high liquefaction potential used as a working assumption in all maps. The Gokarna and Tokha Formations at the northern part of the valley contain sand-dominant soil (Fujii and Sakai 2002 and Fig. 2). The Kalimati Formation dominantly comprises clayey silt has a lower liquefaction potential (Fujii and Sakai 2002). The liquefaction potential maps for all cases show that the northern part (Gokarna Formation) has a higher liquefaction potential than the southern (Kalimati Formation) region which complies with expectations considering the dominant constituents of these two materials. This result is expected given the geological nature of the deposits (the Kalimati is mainly clay while the Gorkarna is mainly sand). However, the original liquefaction map shown in Shrestha et al. (1998) (see Fig. 1a) does not follow the geological expectation in the same way as the analysis presented here, or that of Piya (2004) and Piya et al. (2004) when based upon on a database containing more recent ground investigations (Gilder et al. 2019b, 2020).

No severe liquefaction was observed in the Kathmandu Valley during the Gorkha earthquake as discussed in previous studies (e.g., Chiaro et al. 2015; Moss et al. 2017). Based on the present study, this can be attributed to the season of the year in which the Gorkha earthquake occurred. April is peak dry season in the Kathmandu Valley (Fig. 8d). Most of the area in this season has a low potential for liquefaction, therefore, this result matches with the relatively limited evidence of liquefaction damage during that earthquake. If a similar, or larger, earthquake occurred in the future during peak wet season, the soil is expected to liquefy more significantly as shown in the Figs. 8a and $\mathrm{c}$ and $9 \mathrm{a}$ and $\mathrm{c}$. 

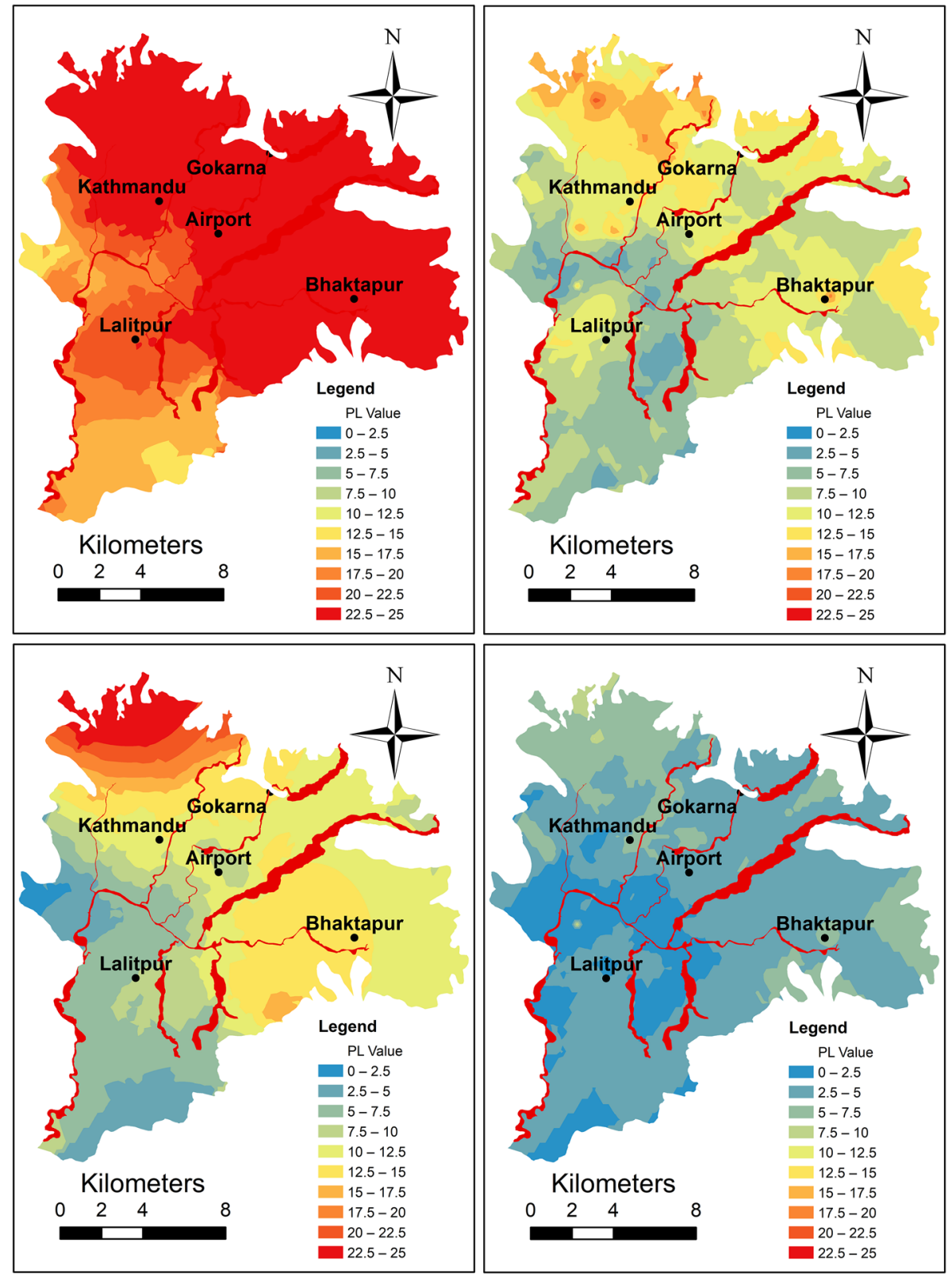

Fig. 9 Liquefaction potential map of the Kathmandu Valley based on PGA assuming the AB03 GMPE for $2 \%$ in 50 years probability of exceedance under a a (top-left) wet scenario and b (top-right) dry scenario and for $10 \%$ in 50 years probability of exceedance in a c (bottom-left) wet scenario and $\mathbf{d}$ (bottom-right) dry scenario, respectively 


\section{Summary and conclusions}

Liquefaction potential zoning maps are useful tools for seismic hazard assessment. In this study, information compiled from geo-database SAFER/GEO-591 was employed to develop new maps of liquefaction potential using SPT data. Notwithstanding the additional information provided by the database, the area of the valley is still not well characterized from a geotechnical perspective and therefore interpolation by ordinary kriging was used to obtain continuous hazard maps of liquefaction potential, developed for different scenarios of hazard-consistent PGA. The following conclusions are drawn:

(a) The effect of changing depth of the water table to simulate seasonal variation was studied which is shown to have a significant effect on the distribution of computed liquefaction potential. This confirms the observations made by Moss et al. (2017) and highlights the need for season-dependent liquefaction susceptibility studies. This is an important issue as it further affects the predictions of structural and infrastructure damage in Kathmandu valley, which are key elements of regional loss assessment.

(b) As expected, the scenario of shallow water table typical of the monsoon season is characterized by higher calculated liquefaction potential with respect to the dry season scenario.

(c) The Gokarna Formation appears to have the highest computed potential for liquefaction with respect to other geological formations studied, which has resulted in maps that indicate higher liquefaction potential in the north of the valley compared to the south (where the composition is more cohesive).

To further refine the above observations, site response analyses at the city level can be performed to calculate the cyclic stress ratio in a more refined manner (De Risi et al. 2019). Currently the liquefaction potential maps are reliant on the available borehole distribution, and it should be noted that some areas are currently not well characterized (e.g., Bhaktapur). It is also expected that the assessment of liquefaction potential of the southernmost valley may increase with data from further investigations if the area is underlain by both weathered fan and deltaic deposits (Sakai et al. 2016). More recent work on liquefaction potential has investigated the role that silts might have on liquefaction potential (Shuttle and Cunning 2007). This may inform further work which may benefit future liquefaction potential studies for the Kathmandu Valley, given the central, most populated parts of the valley are underlain by potentially loose, saturated silts. Further work is also needed to compare the exact locations of observed liquefaction against the results predicted in this work. However, this study has shown the value of the SAFER/GEO-591 (Gilder et al. 2019 b) database for regional estimates of liquefaction potential which may be useful for planning and loss assessment purposes.

\section{Appendix}

See Figs. 10, 11, 12, 13, 14 and 15. 
Fig. 10 Liquefaction and sand boiling at Bungmati (Liq. ID 3a in Table 6) [Photo: RM Pokhrel]
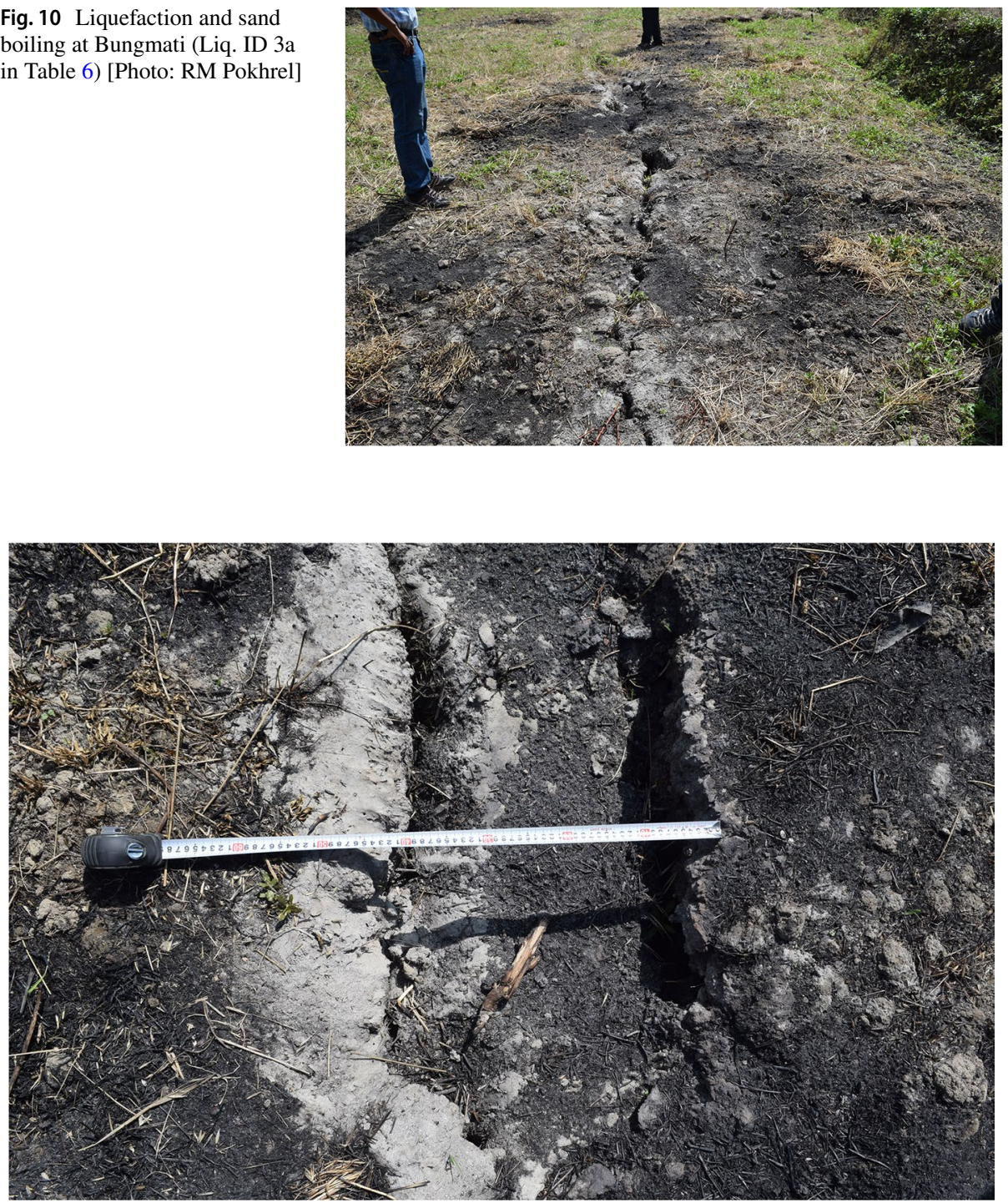

Fig. 11 Liquefaction and sand boiling at Bungmati (Liq. ID 3b in Table 6) [Photo: RM Pokhrel] 


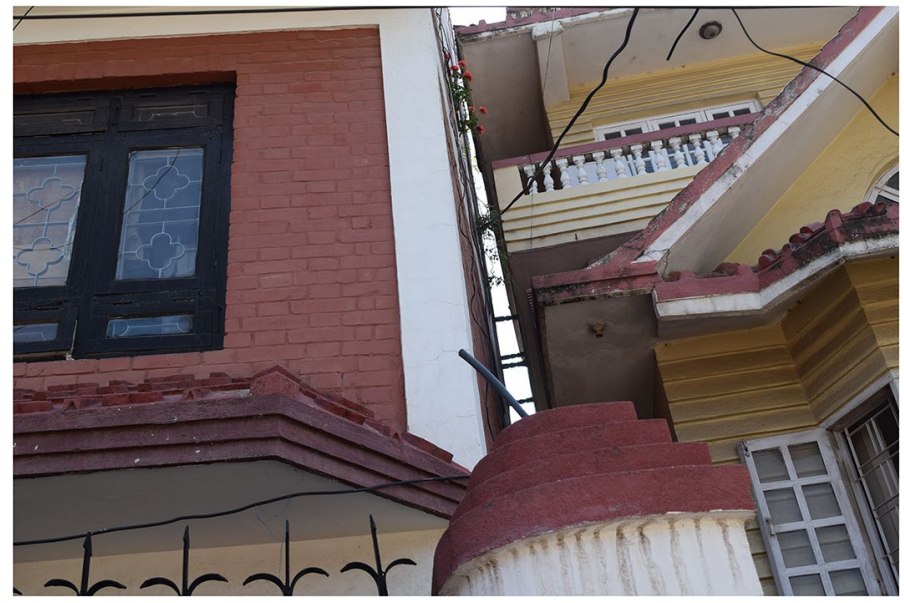

Fig. 12 Tilted building due to liquefaction at Imadol (Liq. ID 6 in Table 6) [Photo: RM Pokhrel]

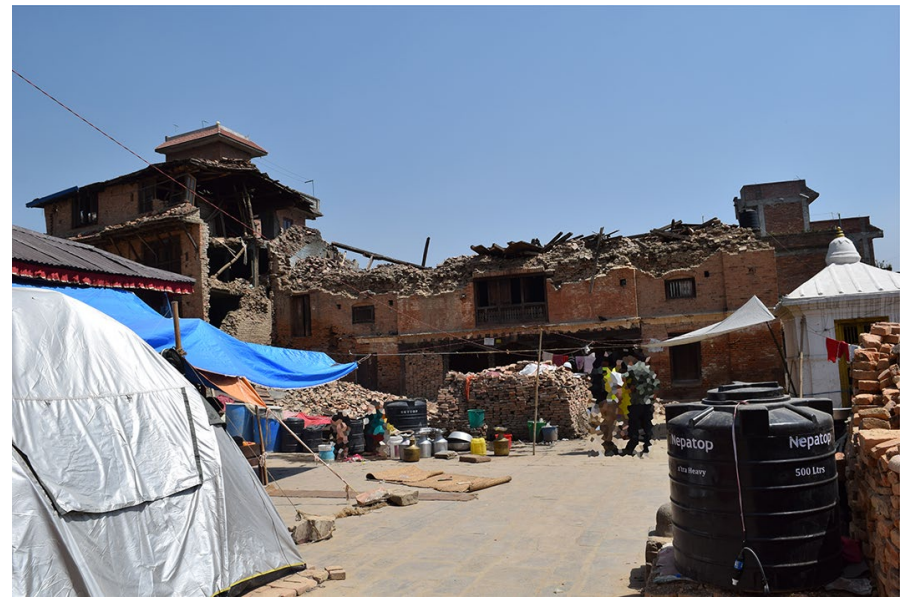

Fig. 13 Structure damage observed at Bungmati village near Bhainsepati-no evidence of liquefaction (Liq. ID 8 in Table 6) [Photo: RM Pokhrel] 


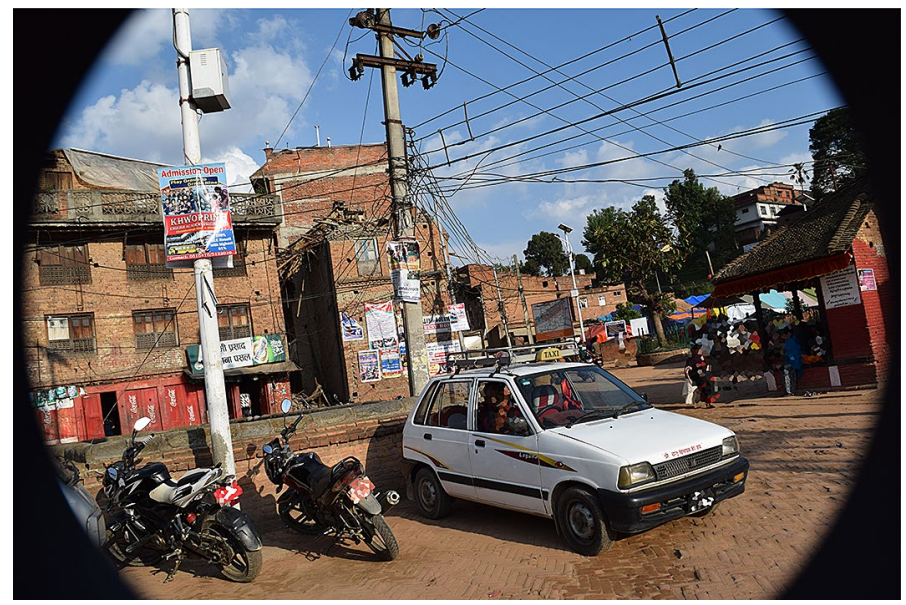

Fig. 14 Structure damage observed at Jagati-no evidence of liquefaction (Liq. ID 9 in Table 6) [Photo: RM Pokhrel]

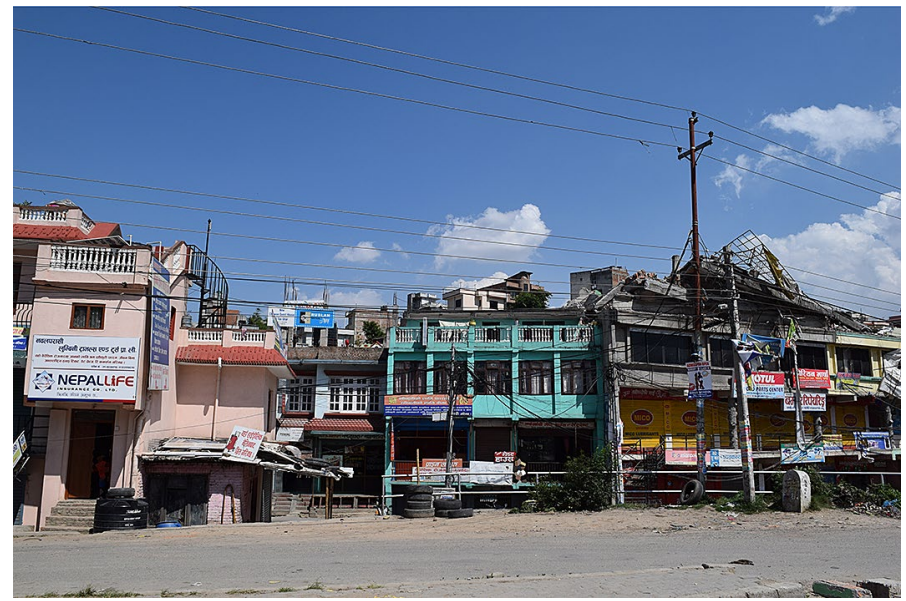

Fig. 15 Structural damage observed at Kalanki near solti-no evidence of liquefaction (Liq. ID 10 in Table 6) [Photo: RM Pokhrel]

Funding The authors acknowledge the support from the Engineering and Physical Science Research Council (EPSRC) project 'Seismic Safety and Resilience of Schools in Nepal' SAFER (EP/P028926/1). The second author acknowledges the support of EPSRC (EP/R51245X/1).

Data availability and material The PGA data used in this study can be downloaded from Stevens (2020) (https://vickystevens.shinyapps.io/Nepal_seismichazard/) and the SAFER/GEO-591 data can be downloaded from Gilder et al. (2019b) (https://doi.org/10.5523/bris.3gjcvx511npuv269xsa1yrb0rw).

Conflict of interest The authors declare that they have no conflict of interest.

Open Access This article is licensed under a Creative Commons Attribution 4.0 International License, which permits use, sharing, adaptation, distribution and reproduction in any medium or format, as long as you give appropriate credit to the original author(s) and the source, provide a link to the Creative Commons 
licence, and indicate if changes were made. The images or other third party material in this article are included in the article's Creative Commons licence, unless indicated otherwise in a credit line to the material. If material is not included in the article's Creative Commons licence and your intended use is not permitted by statutory regulation or exceeds the permitted use, you will need to obtain permission directly from the copyright holder. To view a copy of this licence, visit http://creativecommons.org/licenses/by/4.0/.

\section{References}

Allen TI, Wald DJ (2009) On the use of high-resolution topographic data as a proxy for seismic site conditions (VS30). Bull Seismol Soc Am 99(2A):935-943. https://doi.org/10.1785/0120080255

Atkinson GM, Boore DM (2003) Empirical ground-motion relations for subduction zone earthquakes and their applications to Cascadia and other regions. Bull Seismol Soc Am 93(4):1703-1729. https://doi. org/10.1785/0120020156

Baise LG, Lenz JA (2006) Guidelines for regional liquefaction hazard mapping. Final technical report for U.S. Geological survey award No. 05HQGR0103, United States Geological Survey. Reston. VA, USA.

Bajaj K, Anbazhagan P (2019) Regional stochastic GMPE with available recorded data for active regionApplication to the Himalayan region. Soil Dyn Earthq Eng 126:105825. https://doi.org/10.1016/j.soild yn. 2019.105825

Baker JW, Faber MH (2008) Liquefaction risk assessment using geostatistics to account for soil spatial variability. J Geotech Geoenviron Eng (ASCE) 134(1):14-23. https://doi.org/10.1061/(ASCE)10900241(2008)134:1(14)

Bilham R (1995) Location and magnitude of the 1833 Nepal earthquake and its relation to the rupture zones of contiguous great Himalayan earthquakes. Curr Sci 69(2):101-128

Bilham R (2019) Himalayan earthquakes: a review of historical seismicity and early 21 st century slip potential. Geol Soc, London, Spl Publ 483:423-482. https://doi.org/10.1144/SP483.16

Central Bureau of Statistics (CBS) (2012). National Population and Housing Census 2011, National Report, Government of Nepal, November 2012.

Chaulagain H, Rodrigues H, Silva V, Spacone E, Varum H (2015) Seismic risk assessment and hazard mapping in Nepal. Nat Hazards 78(1):583-602. https://doi.org/10.1007/s11069-015-1734-6

Chen WP, Molnar P (1977) Seismic moments of major earthquakes and the average rate of slip in central Asia. J Geophys Res 82(20):2945-2969. https://doi.org/10.1029/JB082i020p02945

Chiaro G, Kiyota T, Pokhrel RM, Goda K, Katagiri T, Sharma K (2015) Reconnaissance report on geotechnical and structural damage caused by the 2015 Gorkha Earthquake, Nepal. Soils Found 55(5):10301043. https://doi.org/10.1016/j.sandf.2015.09.006

Chung JW, Rogers JD (2011) Simplified method for spatial evaluation of liquefaction potential in the St. Louis area. J Geotech Geoenviron Eng (ASCE) 137(5):505-515. https://doi.org/10.1061/(ASCE)GT. 1943-5606.0000450

De Risi R, De Luca F, Gilder CEL, Pokhrel RM, Vardanega PJ (2021) The SAFER geodatabase for the Kathmandu valley: Bayesian kriging for data-scarce regions. Earthq Spectra 37(2):1108-1126. https:// doi.org/10.1177/8755293020970977

De Risi R, Wang S, Werner MJ, De Luca F, Vardanega PJ, Pokhrel RM, Maskey PN, Sextos A (2020) Simulation-based PSHA for the Kathmandu Valley: Sensitivity to hypocentre randomisation. In: Proceedings of the 17th world conference on earthquake engineering (17WCEE), Paper No. 1c-0040. 9pp.

De Risi R, Penna A, Simonelli AL (2019) Seismic risk at urban scale: the role of site response analysis. Soil Dyn Earthq Eng 123:320-336. https://doi.org/10.1016/j.soildyn.2019.04.011

Elliott JR, Jolivet R, González PJ, Avouac JP, Hollingsworth J, Searle MP, Stevens VL (2016) Himalayan megathrust geometry and relation to topography revealed by the Gorkha earthquake. Nat Geosci 9(2):174-180. https://doi.org/10.1038/NGEO2623

Environmental Systems Research Institute (ESRI) (2012). ArcGIS 10.1. Environmental Systems Research Institute, Redlands, CA, USA.

European Committee for Standardization (CEN) (2004) Eurocode 8: Design of Structures for Earthquake Resistance-Part 1: General rules, seismic actions and rules for buildings. CEN, Brussels

Fan Y, Li H, Miguez-Macho G (2013) Global patterns of groundwater table depth. Science 339(6122):940943. https://doi.org/10.1126/science.1229881

Fujii R, Sakai H (2002) Paleoclimatic changes during the last 2.5 myr recorded in the Kathmandu Basin, Central Nepal Himalayas. J Asian Earth Sci 20(3):255-266. https://doi.org/10.1016/S1367-9120(01) 00048-7 
Gautam D, de Magistris FS, Fabbrocino G (2017) Soil liquefaction in Kathmandu valley due to 25 April 2015 Gorkha, Nepal earthquake. Soil Dyn Earthq Eng 97:37-47. https://doi.org/10.1016/j.soildyn. 2017.03.001

Geyin M, Baird AJ, Maurer BW (2020) Field assessment of liquefaction prediction models based on geotechnical versus geospatial data, with lessons for each. Earthq Spectra 36(3):1386-1411. https://doi. org/10.1177/8755293019899951

Gilder CEL, De Risi R, De Luca F, Vardanega PJ, Holcombe EA, Ayoubi P, Asimaki D, Pokhrel RM, Sextos A (2018) Optimising resolution and improvement strategies for emerging geodatabases in developing countries. In: Proceedings of the $16^{\text {th }}$ European conference on earthquake engineering, european association for earthquake engineering (EAEE), Paper No. 10743.

Gilder CEL, Pokhrel RM, Vardanega PJ (2019a) A ground investigation to inform earthquake hazard assessment in the Kathmandu Valley, Nepal. In: $17^{\text {th }}$ European conference on soil mechanics and geotechnical engineering, (XVII ECSMGE-2019), Reykjavik, Iceland, < https://www.ecsmge-2019.com/uploa ds/2/1/7/9/21790806/0110-ecsmge-2019_gilder.pdf > (14/06/2021)

Gilder CEL, Pokhrel RM, Vardanega PJ (2019b) The SAFER Borehole database (SAFER/GEO-591): User manual, December 2019, v1.1. University of Bristol, Bristol, UK. https://doi.org/10.5523/bris.3gjcv x51lnpuv269xsa1yrb0rw

Gilder CEL, Pokhrel RM, Vardanega PJ, De Luca F, De Risi R, Werner MJ, Asimaki D, Maskey PN, Sextos A (2020) The SAFER geodatabase for the Kathmandu Valley: geotechnical and geological variability. Earthq Spectra 36(3):1549-1569. https://doi.org/10.1177/8755293019899952

Gilder CEL, Pokhrel RM, De Luca F, Vardanega PJ (2021) Insights from CPTu and seismic cone penetration testing in the Kathmandu Valley, Nepal. Front Built Environ 7:646009. https://doi.org/10.3389/ fbuil.2021.646009

Goda K, Kiyota T, Pokhrel RM, Chiaro G, Katagiri T, Sharma K, Wilkinson S (2015) The 2015 Gorkha Nepal earthquake: insights from earthquake damage survey. Front Built Environ 1:8. https://doi.org/10. 3389/fbuil.2015.00008

Grandin R, Vallée M, Satriano C, Lacassin R, Klinger Y, Simoes M, Bollinger L (2015) Rupture process of the $\mathrm{Mw}=7.92015$ Gorkha earthquake (Nepal): insights into Himalayan megathrust segmentation. Geophys Res Lett 42(20):8373-8382. https://doi.org/10.1002/2015GL066044

Habibullah BM, Pokhrel RM, Kuwano J, Tachibana S (2012) GIS-based soil liquefaction hazard zonation due to earthquake using geotechnical data. Int J GEOMATE 2(1):154-160

Hashash YMA, Tiwari B, Moss RES, Asimaki D, Clahan KB, Kieffer DS, Dreger DS, Macdonald A, Madugo CM, Mason HB, Pehlivan M, Rayamajhi D, Acharya I, Adhikari B (2015) Geotechnical field reconnaissance: Gorkha (Nepal) Earthquake of April 252015 and Related Shaking Sequence. Geotechnical Extreme Event Reconnaissance GEER Association, Report No. GEER-040. Version 1.1. https://doi.org/ $10.18118 / \mathrm{G} 61591$

Iwasaki T, Tatsuoka F, Tokida K, Yasuda S (1978) A practical method for assessing soil liquefaction potential based on case studies at various sites in Japan, In: Proceedings of the 2nd International conference on microzonation, San Francisco, CA, USA, vol. 2, pp. 885-896.

Iwasaki T, Tokida K, Tatsuoka F, Watanabe S, Yasuda S, Sato H (1982) Microzonation for soil liquefaction potential using simplified methods. In: Proceedings of 3rd International earthquake microzonation conference, Seattle, pp. 1319-1330.

Iwasaki T, Arakawa T, Tokida K (1984) Simplified procedures for assessing soil liquefaction during earthquakes. Int J Soil Dyn Earthq Eng 3(1):49-58. https://doi.org/10.1016/0261-7277(84)90027-5

Jha SK, Karki B, Bhattarai A (2020) Deterministic and probabilistic evaluation of liquefaction potential: a case study from 2015 Gorkha (Nepal) earthquake. Geotech Geol Eng 38(4):4369-4384. https://doi.org/10. 1007/s10706-020-01277-7

J-RAPID (2016). Japan-Nepal Urgent Collaborative Projects regarding the April 2015 Nepal earthquake within the J-Rapid Program: Investigation of foundation liquefaction susceptibility in the Kathmandu Valley, Final Report.

Katel TP, Upreti BN, Pokharel GS (1996) Engineering properties of fine grained soils of Kathmandu Valley Nepal. J Nepal Geol Soc 14:121-138. https://doi.org/10.3126/jngs.v14i0.32401

Khatakho R, Gautam D, Aryal KR, Pandey VP, Rupakhety R, Lamichhane S, Liu Y-C, Abdouli K, Talchabhadel R, Thapa BR, Adhikari R (2021) Multi-hazard risk assessment of Kathmandu Valley, Nepal. Sustainability 13(10):5369. https://doi.org/10.3390/su13105369

Koester JP, Tsuchida T (1988) Earthquake-induced liquefaction of fine-grained soils-considerations from Japanese research. Miscellaneous Paper GL-88-34. US Army Corps of Engineers, Washington, DC, USA.

Kottek M, Grisser J, Beck C, Rudolf B, Rubel F (2006) World map of the Koppen-Geiger climate classification updated. Meterologische Zeitschrift 15(3):259-263. https://doi.org/10.1127/0941-2948/2006/0130 
Liu CN, Chen CH (2006) Mapping liquefaction potential considering spatial correlations of CPT measurements. J Geotech Geoenviron Eng (ASCE) 132(9):1178-1187. https://doi.org/10.1061/(ASCE)1090-0241(2006) $132: 9(1178)$

Liu CN, Chen CH (2010) Spatial correlation structures of CPT data in a liquefaction site. Eng Geol 111:43-50. https://doi.org/10.1016/j.enggeo.2009.12.002

Liu F (2008) Data discovery on liquefaction-induced lateral ground deformations. Ph.D. thesis, University of Southern California, CA, USA.

Maruyama Y, Yamazaki F, Mizuno K, Tsuchiya Y, Yogai H (2010) Fragility curves for expressway embankments based on damage datasets after recent earthquakes in Japan. Soil Dyn Earthq Eng 30(11):11581167. https://doi.org/10.1016/j.soildyn.2010.04.024

Moss RES, Thompson EM, Kieffer DS, Tiwari B, Hashash YMA, Acharya I, Adhikari BR, Asimaki D, Clahan KB, Collins BD, Dahal S, Jibson RW, Khadka D, Macdonald A, Madugo CLM, Mason HB, Pehlivan M, Rayamajhi D, Uprety S (2015) Geotechnical effects of the 2015 magnitude 7.8 Gorkha, Nepal, earthquake and aftershocks. Seismol Res Lett 86(6):1514-1523. https://doi.org/10.1785/0220150158

Moss RES, Baise LG, Zhu J, Kadkha D (2017) Examining the discrepancy between forecast and observed liquefaction from the 2015 Gorkha, Nepal, earthquakes. Earthq Spectra 33(S1):S73-S83. https://doi.org/10. 1193/120316EQS220M

Nepal National Building Code (NBC) (1994). Nepal National Building Code NBC 105:1994, Seismic Design of Buildings in Nepal. Government of Nepal Ministry of Physical Planning and works, Department of Urban Development and Building Construction. Babarmahal, Kathmandu, Nepal.

Nepal National Building Code (NBC) (2020). Nepal National Building Code NBC 105:2020, Seismic Design of Buildings in Nepal. Government of Nepal Ministry of Urban Development, Department of Urban Development and Building Construction. Babarmahal, Kathmandu, Nepal.

Pandey MR, Molnar P (1988) The distribution of intensity of the Bihar-Nepal earthquake 15 January 1934 and bounds of the extent of the rupture zone. J Nepal Geol Soc 5(1):22-44. https://doi.org/10.3126/jngs.v5i1. 32559

Pandey MR, Chitrakar GR, Kafle B, Sapkota SN, Rajaure S, Gautam UP (2002) Seismic hazard map of Nepal. Department of Mines and Geology, Kathmandu, Nepal.

Pandey VP, Shrestha S, Kazama F (2012) Groundwater in the Kathmandu Valley: development dynamics, consequences and prospects for sustainable management. Eur Water 37:3-14

Paudel MR, Sakai H (2009) Stratigraphy and depositional environment of late Pleistocene Sunakothi Formation in Kathmandu Basin, Central Nepal. J Nepal Geol Soc 39:33-44. https://doi.org/10.3126/jngs.v39i0. 31486

Piya BK (2004) Generation of a geological database for the liquefaction hazard assessment in Kathmandu Valley. M.Sc. thesis, International Institute for Geo-Information Science and Earth Observation, Enschede, The Netherlands.

Piya B, Van Western C, Woldai T (2004) Geological database for liquefaction hazard analysis in the Kathmandu valley, Nepal. J Nepal Geol Soc 30:141-152. https://doi.org/10.3126/jngs.v30i0.31704

Pokharel AK, Hallett J (2015) Distribution of rainfall intensity during the summer monsoon season over Kathmandu, Nepal. Weather 70(9):257-261. https://doi.org/10.1002/wea.2544

Pokhrel R, Kuwano J, Tachibana S (2010) Liquefaction hazard zonation mapping of the Saitama City, Japan. J Nepal Geol Soc 40:69-76. https://doi.org/10.3126/jngs.v40i0.23598

Pokhrel RM, Kuwano J, Tachibana S (2012) Geostatistical analysis for spatial evaluation of liquefaction potential in Saitama city. Lowland Technol Int 14(1):45-51

Pokhrel RM, Kuwano J, Tachibana S (2013) A kriging method of interpolation used to map liquefaction potential over alluvial ground. Eng Geol 152(1):26-37. https://doi.org/10.1016/j.enggeo.2012.10.003

Pokhrel RM, Gilder CEL, Vardanega PJ, De Luca F, Werner MJ, Maskey PN (2019a) Estimation of $V_{S 30}$ by HVSR method at a site in the Kathmandu Valley, Nepal. In: 2nd International conference on earthquake engineering and post disaster reconstruction planning (ICEE-PDRP), Bhaktapur, Nepal, pp. 52-60.

Pokhrel RM, De Risi R, Werner M, De Luca F, Vardanega PJ, Maskey PN, Sextos A (2019b) Simulation-based PSHA for the Kathmandu Basin in Nepal. In: 13th International conference on applications of statistics and probability in civil engineering (ICASP13), Seoul, South Korea. < http://hdl.handle.net/10371/ $153478>(14 / 06 / 2021)$.

Rajendran CP, John B, Rajendran K, Sanwal J (2016) Liquefaction record of the great 1934 earthquake predecessors from the north Bihar alluvial plains of India. J Seismol 20(3):733-745. https://doi.org/10.1007/ s10950-016-9554-Z

Rana BS (1935) Nepal Ko Maha Bhukampa (The great earthquake of Nepal). Jorganesh Press, Kathmandu (in Nepali) 
Sajan KC, Bhochhibhoya S, Adhikari P, Adhikari P, Gautam D (2020) Probabilistic seismic liquefaction hazard assessment of Kathmandu valley, Nepal. Geomat, Natural Hazards Risk 11(1):259-271. https://doi. org/10.1080/19475705.2020.1718220

Sakai H, Fuji R, Sugimoto M, Setoguchi R, Raj Paudel M (2016) Two times lowering of lake water at around 48 and $38 \mathrm{ka}$, caused by possible earthquakes, recorded in the Paleo-Kathmandu lake, central Nepal Himalaya. Earth, Planets Space. https://doi.org/10.1186/s40623-016-0413-5

Sakai T, Gajurel AP, Tabata H, Ooi N, Takagawa T, Kitagawa H, Upreti BN (2008) Revised lithostratigraphy of fluvio-lacustrine sediments comprising northern Kathmandu basin in central Nepal. J Nepal Geol Soc $37: 25-44$

Sapkota SN, Bollinger L, Perrier F (2016) Fatality rates of the Mw 8.2, 1934, Bihar-Nepal earthquake and comparison with the April 2015 Gorkha earthquake. Earth, Planets Space. https://doi.org/10.1186/ s40623-016-0416-2

Seed HB, Idriss IM (1971) Simplified Procedure for Evaluating soil liquefaction potential. J Soil Mech Found Div (ASCE) 97(9):1249-1273

Sharma K, Deng L (2019) Reconnaissance report on geotechnical engineering aspect of the 2015 Gorkha, Nepal, earthquake. J Earthq Eng 23(3):512-537. https://doi.org/10.1080/13632469.2017.1342299

Shrestha P, Tamrakar NK (2013) Morphometry and geomorphic development of the Bagmati River Basin, Nepal Himalaya. J Nepal Geol Soc 46:41-56. https://doi.org/10.3126/jngs.v46i0.31582

Shrestha M, Tamrakar NK (2018) Spatial variability of shallow groundwater level in the Northern Kathmandu Valley. J Nepal Geol Soc 55(1):45-54. https://doi.org/10.3126/jngs.v55i1.22788

Shrestha OM, Koirala A, Karmacharya SL, Pradhananga UB, Pradhan R, Karmacharya R (1998) Engineering and environmental geological map of the Kathmandu Valley (1:50,000) Dept. Mines and Geology, His Majesty's Government of Nepal.

Shuttle DA, Cunning J (2007) Liquefaction potential of silts from CPTu. Can Geotech J 44(1):1-19. https:// doi.org/10.1139/T06-086

Sonmez H (2003) Modification of the liquefaction potential index and liquefaction susceptibility mapping for a liquefaction-prone area (Inegol, Turkey). Environ Geol 44(7):862-871. https://doi.org/10.1007/ s00254-003-0831-0

Sonmez H, Gokceoglu C (2005) A liquefaction severity index suggested for engineering practice. Environ Geol 48(1):81-91. https://doi.org/10.1007/s00254-005-1263-9

Stevens, V.L. (2020). PSHA of Nepal. Data-set available from < https://vickystevens.shinyapps.io/Nepal_ seismichazard/ > (accessed 30/06/2020).

Stevens VL, Shrestha SN, Maharjan DK (2018) Probabilistic seismic hazard assessment of Nepal. Bull Seismol Soc Am 108(6):3488-3510. https://doi.org/10.1785/0120180022

Szeliga W, Hough S, Martin S, Bilham R (2010) Intensity, magnitude, location, and attenuation in India for felt earthquakes since 1762. Bull Seismol Soc Am 100(2):570-584. https://doi.org/10.1785/01200 80329

Thompson EM, Baise LG, Kayen RE, Tanaka Y, Tanaka H (2010) A geostatistical approach to mapping site response spectral amplifications. Eng Geol 114(3-4):330-342. https://doi.org/10.1016/j.enggeo.2010. 05.010

Thompson EM, Wald DJ, Worden CB (2014) A VS30 map for California with geologic and topographic constraints. Bull Seismol Soc Am 104(5):2313-2321. https://doi.org/10.1785/0120130312

Tsuchida, H. (1970). Prediction and Countermeasure against Liquefaction in Sand Deposits. Abstract of the Seminar of the Port and Harbour Research Institute, Ministry of Transport, Yokosuka, Japan, pp. 3.1-3.33 (In Japanese).

UNDP/UNCHS (HABITAT). (1993). Seismic Hazard Mapping and Risk Assessment for Nepal. Prepared for Ministry of Housing and Physical Planning (MoHPP), His Majesty's Government of Nepal (HMG), the United Nations Development Programme (UNDP), United Nations Centre for Human Settlements (HABITAT) and Beca Worley International (New Zealand). In association with SILT Consultants, TAEC Consult, Golder Associates (Canada) and Urban Regional Research (USA). Report No. NEP/88/054/21.03.

Valverde-Palacios I, Vidal F, Valverde-Espinosa I, Martín-Morales M (2014) Simplified empirical method for predicting earthquake-induced settlements and its application to a large area in Spain. Eng Geol 181:58-70. https://doi.org/10.1016/j.enggeo.2014.08.009

Wald DJ, Allen TI (2007) Topographic slope as a proxy for seismic site conditions and amplification. Bull Seismol Soc Am 97(5):1379-1395. https://doi.org/10.1785/0120060267

Wald DJ, Quitoriano V, Heaton TH, Kanamori H (1999) Relationship between peak ground acceleration, peak ground velocity, and modified intensity in California. Earthq Spectra 15(3):557-564. https://doi. org/10.1193/1.1586058 
Yoshida M, Gautam P (1988) Magnetostratigraphy of Plio-Pleistocene lacustrine deposits in the Kathmandu Valley, Central Nepal. Proceed Indian Nat Sci Acad 54A(3):410-417

Yoshida M, Igarashi Y (1984) Neogene to Quaternary lacustrine sediments in the Kathmandu Valley, Nepal. J Nepal Geol Soc 4:73-100

Publisher's Note Springer Nature remains neutral with regard to jurisdictional claims in published maps and institutional affiliations.

\section{Authors and Affiliations}

\section{Rama M. Pokhrel ${ }^{1}$ (D) . Charlotte E. L. Gilder ${ }^{1}$ (D) Paul J. Vardanega ${ }^{1}$ (D) . Flavia De Luca ${ }^{1}$ (D) Raffaele De Risi ${ }^{1}$ (D) Maximilian J. Werner ${ }^{2}$ (D) Anastasios Sextos ${ }^{1}$ (D)}

Rama M. Pokhrel

pokhrelrmohan@gmail.com

Charlotte E. L. Gilder

cg9173@bristol.ac.uk

Flavia De Luca

flavia.deluca@bristol.ac.uk

Raffaele De Risi

raffaele.derisi@bristol.ac.uk

Maximilian J. Werner

max.werner@bristol.ac.uk

Anastasios Sextos

a.sextos@bristol.ac.uk

1 Department of Civil Engineering, University of Bristol, Bristol, UK

2 School of Earth Sciences, University of Bristol, Bristol, UK 